\title{
The Status and Distribution of the Whooper Swan Cygnus cygnus in Russia I: Western Russia and Western Siberia
}

\author{
Mark A. Brazil* and Jevgeni Shergalin**
}

\begin{abstract}
Most of the range of the Whooper Swan Cygnus cygnus falls within the borders of Russia and the associated republics. Although most research on this species has been conducted in Europe and Japan, a growing body of work has been developed since 1980 in Russia. As this work has mostly appeared only in Russian, and often in local journals, the accessibility and availability of that literature to non-Russian scientists has been extremely limited. We have compiled and reviewed the Russian literature, as it pertains to this species, from four regions. We have also attempted to give an overview of the populations, their breeding biology, wintering range, migration, and moulting behaviour in: 1) Western Russia (west of the Ural Mountains), 2) Western Siberia (east of the Urals and west of the Yenisei River, 3) Central and Eastern Siberia (from the Yenisei to the Lena), and 4) The Russian Far East (from the Lena to the Bering Sea). Each of these four regions is as large, or considerably larger than the area occupied by the European population, which is currently the only region for which accurate information on population size is available.

The Whooper Swan population in Russia is large, generally secure, and seemingly expanding its range northwards. It suffers from a wide range of anthropogenic influences, including disturbance, habitat degradation, habitat loss, and hunting, but in some areas is also re-occupying breeding haunts where such negative influences have declined. The Whooper Swan ranges in Russia from the Kola Peninsula in the northwest east to the Anadyr Valley of Chukotka and to Kamchatka. The northern limit to its range lies close to $67^{\circ}-68^{\circ} \mathrm{N}$. There is circumstantial evidence for a continued general expansion of its breeding range northwards. The breeding range extends south to $62^{\circ} \mathrm{N}$ in western parts of European Russia, but as far south as $55^{\circ} \mathrm{N}$ to $50^{\circ} \mathrm{N}$ in Sakhalin and Kamchatka. It winters south to $47^{\circ}-50^{\circ} \mathrm{N}$ in the west, however its southernmost wintering grounds are in Japan where for climatic reasons it can be found in large numbers at latitudes as low as between $35^{\circ} \mathrm{N}$ and $40^{\circ} \mathrm{N}$. In Russia, the Whooper Swan is a breeding bird of the northern taiga, of forest-tundra, and in some places of the tundra too. Human influences during the mid $20^{\text {th }}$ century have, in some areas, particularly in the west, greatly reduced the Whooper Swan's population and range below $19^{\text {th }}$ century and early $20^{\text {th }}$ century levels. Over the latter part of the $20^{\text {th }}$ century, however, it has begun to re-occupy its former range. Population estimates vary enormously even for the same regions making overall estimation of the population virtually impossible. For example estimates for Western Russia and Western Siberia range from as few as 10,000 to more than 100,000 (Ravkin 1991, Rees et al. 1997). There is considerable room for further research in this the largest portion of the Whooper Swan's range. The population of the Russian Far East is thought likely to be in the region of 60,000 birds based on numbers wintering in Kamchatka, Japan, the Korean Peninsula and China.
\end{abstract}

Although the majority of the Whooper Swan's world population breeds in Russia,

Received 15 May 2002, Revised 2 July 2002, Accepted 20 July 2002.

* Department of Environmental Systems, Rakuno Gakuen University, 582-1 Midorimachi, Bunkyodai, Ebetsu-shi, Hokkaido, 069-8501 Japan. E-mail: markbrazil@compuserve.com

** “Zoolit”, Sopruse pst. 175-58, Tallinn 13413, Estonia. E-mail: zoolit@hotmail.com 
most of these birds migrate to areas beyond Russian borders to winter in adjacent countries, around the Baltic Sea, the Caspian Sea, and the Sea of Japan. The timing of migration varies from region to region, but in autumn at least does seem largely driven by sharp falls in temperature, particularly of daytime temperatures from $5^{\circ} \mathrm{C}$ to $0^{\circ} \mathrm{C}$. Evidence from widely different areas in Russia point to spring and autumn migration taking place in different waves. In spring, pairs and families predominate among early migrants, nonbreeders among later migrants. In autumn, non-breeders migrate earlier than breeders, as evidenced by the very low proportion of young in migratory flocks early in the season, and the high presence of pairs, families and flocks containing broods during the latter part of the season. In the western part of its range it may be found on migration in company with both Mute Cygnus olor and Tundra (Bewick's) Cygnus columbianus bewickii swans, while in the eastern part of its range it commonly uses the same staging areas as Tundra Swans.

Given the enormity of the Whooper Swan's breeding range within the political boundary of modern Russia, combined with the small number of resident swan biologists, and the difficulty of access to most areas, it is not surprising that even the most basic information is not available for some areas. It is nevertheless impressive that many papers have been published on this species in its Russian range in recent decades. Given the immense scale of the four regions of Russia, we have addressed Western Russia and Western Siberia in this paper and address Central and Eastern Siberia, and the Russian Far East in a subsequent paper (Brazil \& Shergalin in press). Given the enormous extent of suitable habitat for the Whooper Swan in Russia, it is clear that it is to Russia that we must look in the future to clarify the true status of the species.

Key words: Russia, Status, Distribution, Whooper Swan (Cygnus cygnus). キーワード：ロシア，生息状況，分布，オオ八クチョウCygnus cygnus.

\section{Introduction}

The Whooper Swan Cygnus cygnus is a wide-ranging Palaearctic species that has been extensively studied only in the westernmost part of its range in Iceland, the British Isles, Scandinavia, and Continental Europe. It has been studied to a rather lesser extent in Japan, China, and Russia (Brazil in press). The great expanse of Russia not only provides the single largest continuum of northern swan habitat in the world, but it also contains almost all of the Whooper Swan's breeding range (see Fig. 1). Russia's enormous land area $\left(17,075,200 \mathrm{~km}^{2}\right)$, its relatively small human population $(145,470,197$; July 2001 estimate) and low population density (about 8.52 per $\mathrm{km}^{2}$ ) (CIA 2002) and its even lower density of swan biologists has meant that, until recently, relatively little information has been available from the region. The aim of this paper is to review the status and distribution of the Whooper Swan in Russia calling on literature published primarily in Russian since 1980.

Much of what was known in the west about this vast region was until recently based largely on supposition, mainly because very little literature was available except in Russian. There has been little information available on recent changes in the breeding populations of either Whooper or Bewick's Cygnus columbianus bewickii swans in Russia, although some local breeding populations are known to have experienced declines while others have increased (Earnst 1991). Ohtonen (1992), for example, who has studied Whooper Swans for some time in Finland, considered that Whooper Swan densities were 


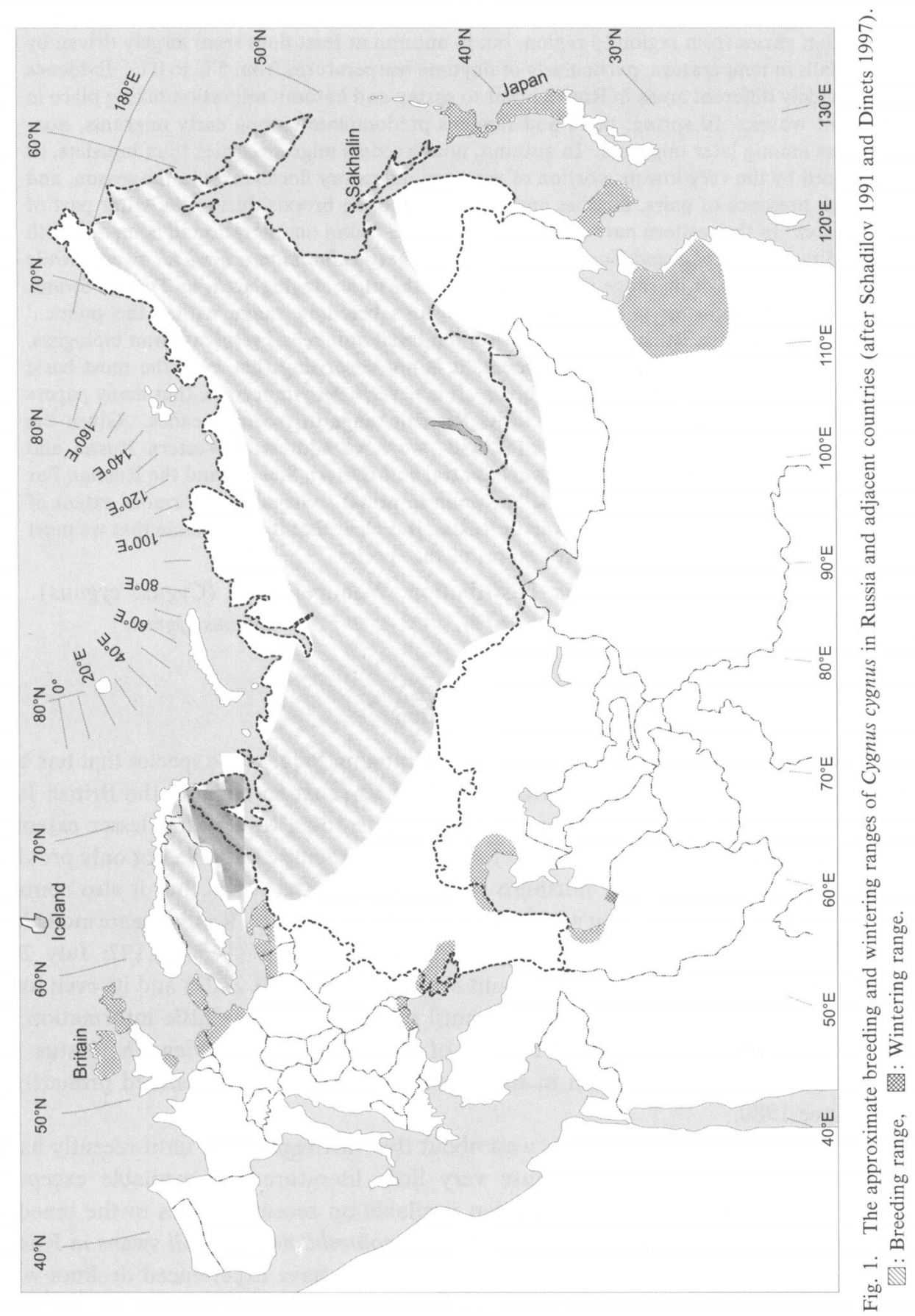


higher in Russia than in Finland, that they increased eastwards, and that during the $20^{\text {th }}$ century the population had probably not declined in Russia as much as it had in Norway, Sweden and Finland. How much of this is fact remains to be seen.

In Russia, the Whooper Swan ranges from the Kola Peninsula in the northwest close to Finland, all the way eastwards to the Anadyr River (R) valley of Chukotka, and Kamchatka in the extreme northeast facing the Pacific Ocean. At its northern extent it can be found beyond the $67^{\text {th }}$ parallel on the northern part of the Kola Peninsula and in the lower (northern) parts of the Pechora R. In Western Siberia, it reaches the $66^{\text {th }}$ parallel in the $\mathrm{Ob} \mathrm{R}$ region, and further east it reaches the $67^{\text {th }}$ parallel in the Taz $\mathrm{R}$ valley. A little further east, in the Yenisei $R$ valley it can be found at $68^{\circ} \mathrm{N}$ and continuing eastwards the northern limit of its range lies close to $67^{\circ}-68^{\circ} \mathrm{N}$. There is circumstantial evidence for a continued general expansion of the breeding range northwards, though the factors influencing this are not yet clear or confirmed (J. Syroechkovskiy Jr in litt 2001).

In the south the Whooper Swan breeds regularly as far south as $62^{\circ} \mathrm{N}$ in western parts of European Russia and south to $55^{\circ} \mathrm{N}$ to $50^{\circ} \mathrm{N}$ in Sakhalin and Kamchatka. It breeds in widely dispersed areas of habitat and towards the southern extent of its range in particular nesting is irregular both in distribution and success. It winters south as far as about $47^{\circ} \mathrm{N}$ on the northern shore of the Caspian Sea, and to $50^{\circ} \mathrm{N}$ in northern Kazakstan, and between $47^{\circ}$ and $50^{\circ} \mathrm{N}$ at Lake Balkhash, Mongolia, across northeastern China, into southern Primor'ye in the region of Lake Khanka. Its southernmost regular wintering grounds are in Japan, where for climatic regions it can be found at latitudes as low as between $35^{\circ} \mathrm{N}$ and $40^{\circ} \mathrm{N}$ in large numbers each winter (Stepanyan 1990, Brazil 1991).

Estimating the Whooper Swan population size of a region that makes up 80-90\% of the species' range is fraught with difficulties and, in the case of the West Siberian population, contradictions too. The 'West Siberian'/Black Sea/'East Mediterranean' population has been suggested to be anything from 17,000 to 250,000 in size, while the West and Central Siberian/Caspian population has variously been put at 20,000 to $250,000^{1}$ birds (see Ravkin et al. 1990, Delany et al. 1999), however, in addition the central Siberian and Eastern Asian population has been estimated to be in the region of 60,000 birds, giving a $1 \%$ threshold for Ramsar Convention criteria of 600 birds in that region, and making it very similar in size to the northwest European population (Laubek et al. 1999, Miyabayashi \& Mundkur 1999).

Despite some regional problems resulting from habitat loss relating to development, all three swan species breeding in Russia, the Mute Cygnus olor, Bewick's and the Whooper, have, nevertheless, been expanding their ranges and increasing in numbers (Schadilov \& Belousova 2001).

Our aim in writing this paper has been primarily to review the distribution and status of the Whooper Swan in Russia and the associated republics, and to provide general information on breeding, migration, wintering and moult in the various regions comprising Russia. Our secondary goal has been to provide an overview of the literature

\footnotetext{
${ }^{1}$ Ravkin et al.'s (1990) higher estimates are virtually impossible to reconcile with other population estimates made from outside the region.
} 
pertaining to this species across this enormous region, almost all of which has only been available in Russian before.

\section{Distribution and Status}

Beginning in the west, four large regions are addressed, which, for the purposes of this paper and our subsequent paper (Brazil \& Shergalin in press), we have defined as follows. We begin with 1) Western Russia, i.e. the region west of the Ural Mountains; continuing eastwards we consider 2) Western Siberia, from the Ural Mountains east to the Yenisei R; then 3) Central and Eastern Siberia, from the Yenisei R east to the Lena R, and finally 4) The Russian Far East from the Lena $R$ east to the Bering Sea. Each of these four regions is as large, or larger, than the whole of the Whooper Swan's European Range.

\section{Western Russia, from Europe to the Ural Mountains}

Western Russia, the first region to consider, spreads eastwards from the Finnish border to the Pechora $\mathrm{R}$ and beyond that to the western slopes of the Ural Mountains, that great geological scar where the European continent and the Asian continents are welded together (see Fig. 2). Whereas this region is rather narrow in the north, in the south it spans from the Ukraine's shores of the Black Sea to the shores of the Caspian Sea. This is a mere fraction of Russia and the republics of the ex USSR, yet alone it is larger than all of Europe. In this region, the Whooper Swan breeds in the northern taiga, amongst forest-tundra and, in certain places, on the tundra too. Its breeding range stretches as far north as the shores of the Barents Sea on the Kanin Peninsula. To the east of the Kanin Peninsula its northern limit is along the shore of Cheshskaya Guba (Bay) and Korovinskaya Guba. It also breeds in the Pechora $\mathrm{R}$ delta at approximately $67^{\circ} \mathrm{N}$ and between the Pechora and Kuya rivers and along the middle reaches of the Shapkina $R$ at the border of the tundra and forest-tundra zones. Further eastwards the Whooper Swan occurs as far north as the northern border of sparse forest on the rivers Kolva (Hoveiver) and Kolvavis (tributary of the Kolva R), along the middle parts of the Hosedayu and Ad'zva rivers, and along the upper parts of the Bolshaya Nertseta, and Bolshaya Rogovaya rivers. From the Bolshaya Rogovaya $\mathbf{R}$ the border of distribution shifts to the south to the lower parts of the Vorkuta and Yun'yakha rivers. Occasionally it breeds in the southern part of the Russkiy Zavorot Peninsula (Malozemel'skaya tundra) and in the shrubby sub-zone of the Bolshezemel'skaya tundra (Mineev 1995).

The status and even the integrity of the population(s) breeding here in Western Russia and wintering in the East Mediterranean/Black Sea and Southwest Asian regions are still in doubt. Are they a single population that divides in winter, or are they separate populations? If separate populations, what is the extent of interchange between them? These questions remain unanswered because of the scale of the area and the difficulties of working in the region. Uncertainties of coverage and variation in coverage hamper comparisons, but there were, for example, 2,364 Whooper Swans wintering in Romania, 574 in the Ukraine and 1,510 in Iran in 1995, while in 1996 there were just 239 in Romania, but 1,810 in the Ukraine (Delany et al. 1999). 


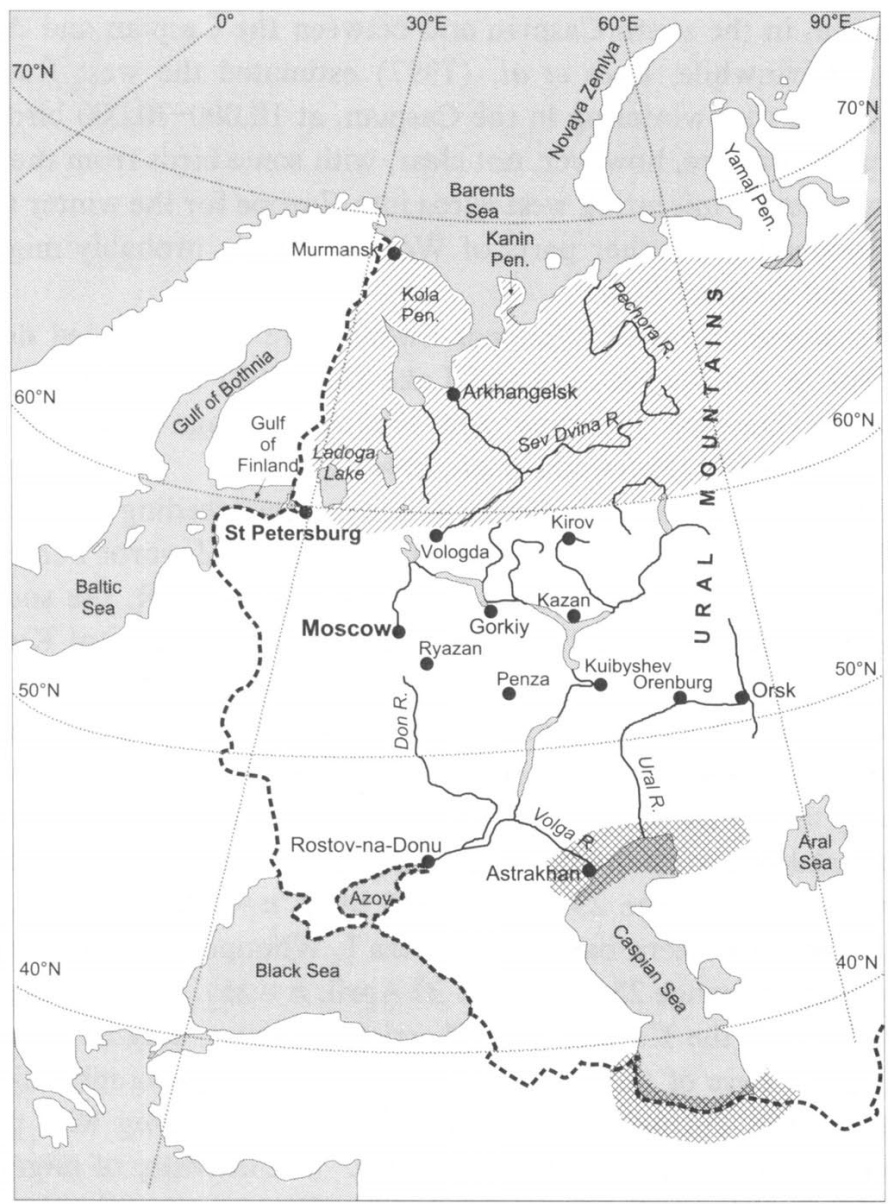

Fig. 2. Western Russia showing the main locations mentioned in the text and the approximate breeding and wintering areas of Cygnus cygnus.

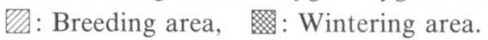

Assessing the population size and trends becomes increasingly more difficult as one moves eastwards. The degree of coverage is low and this, combined with the known effect of hard weather forcing different degrees of movement between years, means that figures are not available. It is thought, however, that numbers wintering in the Black Sea have declined since the early 1970s, while the numbers wintering in the northern Caspian rose to an average of 13,900 between 1970 and 1980 from just 1,850 between 1955 and 1969 (Delany et al. 1999).

Scott \& Rose (1996) considered there to be two populations involved, the 'Western Siberian'/Black Sea/'East Mediterranean' population, estimated to be of 17,000 birds (based on Rüger et al. 1986), and the Western Siberian/Caspian population. This was provisionally estimated at 20,000 birds on the basis of estimates from the northern part of the Caspian Sea amounting to 13,900 birds, with a further 5,000-6,000 wintering else- 
where in the region, in the south Caspian and between the Caspian and Aral seas (Scott \& Rose 1996). Meanwhile, Rees et al. (1997) estimated the west Russian wintering population, including that wintering in the Caspian, at 10,000-70,000 birds. The boundaries of their populations are, however, not clear, with some birds from the northern parts of Western Russia clearly migrating westwards into Europe for the winter (Mineev 1995), while other Whoopers from other parts of Western Russia probably migrate south and reach the Black and Caspian Seas.

Important concentrations of Whooper Swans were also recorded during an Asian Waterfowl Census in Azerbaijan at Aggel Lake (L) (900) and in Turkmenistan in the Amu Darya valley between Druzhba and Nukus (average 300) and also at Lake Sarakamysh (average 850) (Perennou et al. 1994).

In the region west of the Urals during summer, non-breeding birds can be found in flocks, and individually on the northern part of the Russkiy Zavorot Peninsula, along the shore of Bolvanskaya Guba, the lower parts of the Chernaya R, the southern shore of Haipudyr Guba, the lower part of Lymbadayaga and in the region of Karskaya Guba.

The northwesternmost corner of the Western Russia region is where the Kola Peninsula bulges eastwards into the Barents Sea. Research there and among the protected islands of the top of the Gulf of Kandalaksha has shown that birds arrive in spring on the Kola Peninsula by way of the Gulf of Bothnia (Bianki 1990). In spring many swans cross the Gulf of Kandalaksha, with the first appearing as early as 23-24 March, although the average date is 18 April (range 23 March to 5 May; $n=24$ ). In the Lapland Nature Reserve (NR), near the western bank of Imandra L. Whooper Swans appear even earlier, on average on 13 April (range 25 March to 30 April; $n=35$ ). The apparent later arrival of swans in spring from the Kandalaksha Skerries, however, may be connected with the rarity of observation there of the first swans. The peak of spring migration through the Kandalaksha skerries is during the last third of April, coinciding with peak passage in Finland (Bianki 1990, Haapanen \& Hautala 1991). The intensity of migration decreases during the first third of May in the Kandalaksha skerries, but it is still comparatively great.

On the Kola Peninsula the Whooper Swan is a bird of the taiga, and avoids forest-tundra and tundra. It prefers richly vegetated lakes set amidst taiga forest, and nests near water on islands or in aapa-bogs. Aerial surveys during July 1986 revealed that there were three areas of concentration, in taiga around the upper parts of the Ponoi $R$ and also in the Umba $\mathbf{R}$ basin, and in forest-tundra in the area between Kharlovka and Iokanga, a region of lakes and swamps. Non-breeding birds arrive after breeding birds and whereas early migrants are mostly in pairs, the later arrivals are usually in flocks. The total population of the area was estimated to be 1,600-1,700 birds in 1986, about 100-200 more birds than in 1975-1976 (Bianki 1990).

In the western part of the Kola Peninsula is the Lapland NR; there, Bragin (1987), and Semenov-Tyan-Shanskiy \& Gilyazov (1990) have collected materials relating to the period from 1930-1987. Whooper Swans arrive on average on 13 April ( $n=47$ years), ranging from as early as 25 March in 1935 to as late as 30 April 1940, generally at the time when strongly flowing streams and bogs are thawing and at an average air temperature of minus $3.0^{\circ} \mathrm{C}$. They arrive $11-14$ days earlier $100-130 \mathrm{~km}$ to the south and west on the 
Kovda and Girvas rivers. They depart the Lapland NR in autumn as the shallow lake waters freeze on average on 18 October $(n=41)$, although as early as 20 September in 1966 and as late as 30 November in 1950, and with the temperature averaging minus $0.3^{\circ} \mathrm{C}$ on the day of departure. Spring flocks are usually smaller, at 6-15 birds, than those in autumn (10-18, but sometimes 27-50).

Numbers in the Lapland NR fell considerably during the period 1930-1950 but have since recovered to the 1930s level. As elsewhere in the species' range the proportion of the population actively breeding is about $30 \%$, of which only about $60 \%$ breeds successfully (Semenov-Tyan-Shanskiy \& Gilyazov 1990).

In the Murmansk Region, in the north of Karelia, and in the coastal part of the Arkhangelsk Region, Bianki \& Shutova (1987) made aerial surveys of swans in late July and early August 1975-1977. Although species could not be confirmed from the air, ground surveys in the same regions west of Pesha $R$ indicated that all were Whooper Swans, while in the regions of the Pechora and Khaipudyr Guba, most, if not all, were Bewick's Swans. Bianki \& Shutova (1987) found that the highest density of swans in Karelia was among aapa-bogs where they averaged $4.8 / 100 \mathrm{~km}^{2}$. In the southern part of the Kola Peninsula, a region of aapa-bogs and swamp forest, the density of Whooper Swans was highest at $8.3 / 100 \mathrm{~km}^{2}$. As in much of the rest of the species' range they found that only single pairs occupied large lakes, thus in regions where large lakes were commoner, swan densities were lower, conversely, the majority of the broods they encountered in the taiga were at small lakes or in aapa-bogs. Further north the density was lower at $3.3 / 100 \mathrm{~km}^{2}$.

The Umba $R$ basin and the western parts of the Murmansk Region support fewer swans. Breeding occurs only at low density in the Lapland NR. The highest density in this large region was only $3.3 / 100 \mathrm{~km}^{2}$ in the Notozersko-Tulomskaya depression, and the whole of the Murmansk Region has suffered from increased human access and a subsequent decline in swan numbers (Bianki \& Shutova 1987).

To the northeast of a line connecting the top of the Kola Bay with Pyalitsa R mouth, forest-tundra and tundra form a complicated mosaic, however few swans nest here and not every year (Bianki \& Shutova 1987). The highest swan density recorded $(12.2 / 100 \mathrm{sq}$ $\mathrm{km}$ ) was in the Mezen R lowland on the Kanin Peninsula. There, in the 1950s, Whooper Swans nested at considerable densities with pairs as close as $3-5 \mathrm{~km}$ from one another at all lakes visited (Spangenberg \& Leonovich (1960) in Bianki \& Shutova 1987). Densities were lower in the southern parts of the Kanin Peninsula. Near the base of the Kanin Peninsula swan density was less than in its middle regions with $9.5 / 100 \mathrm{~km}^{2}$ on the west bank of the Kuloi R, but only $4.7 / 100 \mathrm{~km}^{2}$ in the interstream area between the Mezen' and Pesha rivers.

Whooper Swans were absent from the tundra region to the east, of the Timan Mountain ridge for example, but in the western part of the Pechora Lowland the swan density rose again to about $8 / 100 \mathrm{~km}^{2}$. In the Bolshezemel'skaya tundra, to the east of Bolvanskaya Guba, and in other tundra regions east of Kolokolkovaya Guba swan densities rose but these were all considered to be Bewick's Swans. In the enormous Pechora R delta, Whooper Swan densities reached very high levels at $28.3 / 100 \mathrm{~km}^{2}$, or 
twice that on the Kanin Peninsula (Bianki \& Shutova 1987).

Bianki \& Shutova (1987) estimated from their aerial survey work (1975-1977) that there were then in the region of 1,250 Whooper Swans in Northern Karelia, 1,510 in the Murmansk Region, and 2,470 in the area around the White Sea part of the Archangelsk Region.

Continuing eastwards from the Kola Peninsula one reaches the Kanin Peninsula, then east of that peninsula, but still west of the Pechora $R$ runs the Indiga $R$, which reaches the Barents Sea close to $49^{\circ} \mathrm{E}$. In the Indiga $\mathrm{R}$ basin, the Whooper Swan breeds on the banks of large glacial lakes, where they are overgrown by grassy and shrubby vegetation including sedges, sabre-grass, horsetails and willows. The highest density occurs along the upper reaches of the Indiga $R$ at 0.3 birds $/ \mathrm{km}^{2}$ (Mineev 2000).

To the north, solitary Whooper Swans have been recorded as vagrants on the Yugor (skiy) Peninsula, and on the Novaya Zemlya Islands in July and August, then in 1995 breeding was confirmed there for the first time on the Southern Island of Novaya Zemlya when a brood was sighted near Vadega-1 $\mathbf{R}$ mouth northeast of Gusinaya Zemlya (Kalyakin 1999). At approximately $72^{\circ} \mathrm{N}$, this is close to the northern limit of the species. There are also archaeological remains of two Whooper Swans from Vaigach, and in October 1987 still non-flying young Whooper Swan cygnets were captured at Varnek settlement (south of Vaigach Island) and kept during the winter then released on the tundra in May 1988 (Kalyakin 1999).

Human influences in Western Russia during the mid $20^{\text {th }}$ century greatly reduced the Whooper Swan's population and range below $19^{\text {th }}$ century and early $20^{\text {th }}$ century levels. Over the latter half of the $20^{\text {th }}$ century it began to re-occupy its former range, the southern border of which stretches from $62^{\circ} 10^{\prime} \mathrm{N}$ at the Russian border, rises to $63^{\circ} 20^{\prime} \mathrm{N}$ in central Karelia before falling to $62^{\circ} \mathrm{N}$ at the eastern border of Karelia with the Archangelsk Region. Continuing eastwards, the southern border is at $61^{\circ} 45^{\prime} \mathrm{N}$ declining to $61^{\circ} 20^{\prime} \mathrm{N}$ at the border with the Vologda Region. South of this line, it breeds irregularly in southern Karelia, in the St Petersburg Region ${ }^{2}$ and north Vologda Region (Hoklova \& Artemjev in press).

In the southern and middle taiga of the Komi Republic (situated in the north-eastern part of Western Russia between the Arkhangelskaya region to the west, north-west and north, and the Permskaya region to the south ${ }^{3}$ ) the Whooper Swan is absent during the breeding season. In the southern taiga it is common only during spring migration when flocks appear briefly on the snowmelt floodwaters and swamps.

East of the Pechora R, in the region along the northern fringe of the Ural Mountains, in the basin of the Upper Pechora $\mathbf{R}$ the Whooper Swan is uncommon and breeding has not been confirmed, however, it is numerous in the basin, and branches of the mid- and lower-reaches of the Pechora R (Mineev 1995). The density of breeding pairs on the Pechora R Delta increased considerably between $1980-2000$, while some $55.9 \%$ to $73.2 \%$

\footnotetext{
${ }^{2}$ In publications prior to 1924 the name St Petersburg was used, however publications dating from the period 1924-1990 used the name Leningrad, while since 1990 it has been renamed St Petersburg.

${ }^{3}$ Syktyvkar, capital of the Komi Republic, is situated at approximately $62^{\circ} \mathrm{N} ; 51^{\circ} \mathrm{E}$.
} 
of Whooper Swans do not defend breeding territories instead they congregate in nonbreeding flocks (Schadilov et al. in press).

Whooper Swans summering and breeding in the forest-tundra and northern-taiga zones of this northern part of Western Russia, from approximately $30^{\circ}-55^{\circ} \mathrm{E}$, migrate mainly to the west and southwest in autumn from the Pechora region, for example, towards the Severnaya Dvina and Onega rivers, and may be joined by birds from as far east as the Yamal Peninsula, which lies to the northeast of the Ural Mountains. They continue, by way of the Gulf of Finland to the southern shores of the Baltic Sea, returning along the same route in spring (Mineev 1995). Prior to the main exodus, concentrations of Whooper Swans occur on the Pechora R delta, and in Korovinskaya and Kolokolkova bays, where thousands of birds concentrate in numerous flocks each of up to 200-300 individuals (Mineev 1995). It is possible that some from the northern breeding range west of the Urals also migrate south towards the Black and Caspian seas.

On spring migrations, the first Whooper Swans arrive in this region east of the Pechora R from about mid April to early May. Even along the Upper Pechora R they may arrive as early as 7-20 April, although along the Lower Pechora $\mathrm{R}$ first arrivals may be 10 days or so later, from 17-20 April. Even on the Timan tundra they arrive as early as in the middle of April indicating that like arrival on the wintering grounds, arrival on the breeding grounds may occur almost simultaneously over vast regions (Mineev 1995).

Migration is frequently via river valleys, with birds arriving in spring either in pairs, or in small flocks of up to 10 birds, although at resting sites they may concentrate into flocks of up to 50 birds (Mineev 1995). In autumn, migration begins first among non-breeding pairs and small flocks, in some years as early as mid September. During the early phase, birds move westwards and southwestwards from one wetland to another resting along the way. In the region of Urdyzhinskoe L (Malozemel'sdkaya tundra) pairs and small flocks of 16-18 birds have been seen annually on migration until 25-28 September. Weather seems a critical factor, and before the first frosts the number of migrants increases sharply. During the last few days of September flocks of 30-100 birds (without broods) are on the move. While the first wave of migrants consists almost entirely of non-breeders, the second wave includes many of the breeders, with pairs, families, and flocks containing broods on passage during early and mid October (Mineev 1995).

The highest population density in the region is in the wetlands of the middle and lower Pechora $\mathrm{R}$ where densities are sometimes as high as $0.98 / \mathrm{km}^{2}$ in some areas. Elsewhere densities range widely from as low as $0.02-0.4 / \mathrm{km}^{2}$ on the Bolshezemel'skaya tundra (Mineev 1995).

In the European part of Russia the main breeding range lies north of $63^{\circ}-64^{\circ} \mathrm{N}$, but the southern border of the regular breeding range is not clear. South of the Kola Peninsula, the Whooper Swan currently breeds commonly south to about $63^{\circ} 30^{\prime} \mathrm{N}$ in Karelia, with birds occasionally summering in southern Karelia although most records involve single birds. In Europe there has been a spate of records of Whooper Swans breeding to the south of their historical range. Such range extension may have also been occurring in western Russia with, for example, birds breeding well south of their normal 
range in the northwest, in the St Petersburg region east of the Gulf of Finland, (approximately $60^{\circ} \mathrm{N}$ ). According to Mikhaleva (1997), until the middle of the $20^{\text {th }}$ century the Whooper Swan bred in the St Petersburg region, since when it has only been a passage migrant through the region. Not only did breeding occur prior to the late $1960 \mathrm{~s}$, however, but it is also known to have occurred in 1986, on the southern shore of Ladoga $\mathrm{L}\left(60^{\circ} 13^{\prime} \mathrm{N} ; 32^{\circ} 05^{\prime} \mathrm{E}\right)$, and subsequently on Valaam Island in Ladoga $\mathrm{L}$ in June $1997^{4}$ (Mikhaleva 1997, Vysotskiy 1998, Golovan \& Kondratiev 1999). There have been occasional breeding records, in recent years, not only in southern Karelia in the Ladoga $\mathrm{L} / \mathrm{St}$ Petersburg region, in the Zaonezh'ye (Trans-Onega $\mathrm{L}$ area), and at Pudozhskiy $\mathrm{L}$ (on the border of Karelia and the Arkhangelsk region to the east), and on the Sukhaya Vodla R in Vodlozerskiy (Vodlozero) National Park (NP). Whooper Swans also breed in the region of Tolvojarvi (Suojarvi district of Karelia) (Khokhlova \& Artem'yev 2000).

The Whooper Swan also bred regularly on Vyal'ye L (Luga district) south of St Petersburg until 1956. After a 10-year absence, a pair summered on the lake in 1967, as they did again in 1998. In May 1999, a nest was found on a small island of old floating vegetation near the eastern shore of the lake at $59^{\circ} 01^{\prime \prime} \mathrm{N} ; 30^{\circ} 14^{\prime \prime} \mathrm{E}$, and in early June a brood of five cygnets was hatched (Golovan \& Kondratiev 1999).

During the period from 1995 to 1999, a new breeding population of Whooper Swans was discovered in the Kenozero NP (which lies between the Kargopol and Plesetsk districts of southeast Karelia and the Arkhangelsk Region at approximately $62^{\circ} \mathrm{N}$ ). This region, situated on the watershed of the White and Baltic Seas, consists of extensive wetlands including extensive almost untouched bogs, which provide apparently ideal breeding habitat for Whooper Swans. Whooper Swans breed annually on certain of the forest lakes in the national park, while at others they only breed occasionally. No total population estimates are available. Breeding pairs with their families have been seen, however, at numerous lakes within the park, over the five-year period up to 1999 , suggesting that there is a secure population. This appears to be the southernmost stable breeding population of Whooper Swans in northwest Russia, occurring as far south as $61^{\circ} 30^{\prime \prime} \mathrm{N}$ (Khokhlova \& Artem'yev 2000).

In the region of the Upper Volga $\mathbf{R}$, the Whooper Swan is a migrant during spring when small flocks (largest 52 birds) occur at swampy wetlands and lakes during late March and during April, such as at Jarkovskiy Mokh and Orshinskiy Mokh, Upper Mologa. Larger concentrations are known in spring from the peat areas of Sokoliy Mokh in the St Petersburg region. In summer 1982 on 30 June, one was seen at Kremno L. They reappear again in autumn from late September until freeze-over in November. During this season they are usually seen singly, in small flocks of up to five birds (presumably families), and sometimes in the company of geese (Nikolaev 1998).

The nearest breeding site is in the Darwin NR $\left(59^{\circ} \mathrm{N} ; 38^{\circ} \mathrm{E}\right)$, situated in the northern part of Rybinsk water reservoir in the Vologda Region, where three pairs have bred since 1983 raising their young in the peat bogs there, and pairs have also bred regularly at lakes in the Ulom bogs in the Ustyuzhinsk district also of the Vologda Region (Nikolaev 1998).

\footnotetext{
${ }^{4}$ Unfortunately the attempt failed when the eggs were eaten by crows (Mikhaleva 1997).
} 
With most of the northern breeding Whoopers migrating westwards and southwest, the Whooper Swan only seems to occur as a rare passage migrant further south. For example in the Ivanovo Region (Ivanovskaya Oblast), in particular on the Unjenskiy spur of the Gorkiy Reservoir (Gor'kovskoye Reservoir) on the Volga R (c57 $\mathrm{N}$; about $200 \mathrm{~km}$ $\mathrm{NE}$ of Moscow), it was seen on migration during April and until 11 May during the period 1960-1965, but only rarely since (Gerasimov et al. 2000).

To the east, in the Kirov Region, particularly the Kama $R$ drainage basin, and Tatarstan, the Whooper Swan is now listed in the local Red Data Book as a rare migrant and a past breeding species (Sotnikov 1999). During the late $19^{\text {th }}$ and early $20^{\text {th }}$ centuries, however, it nested quite commonly across much of the Kirov Region and the southern border of its breeding range crossed Tatarstan, occurring along both large and small rivers and even on small wetlands near settlements. Even by the early 1910s, breeding was reduced to just a few isolated pairs. Wetland drainage and hunting both contributed to the loss of this species as a breeding bird of the area, such that for 40 years (1926-1965) no nests were found in Tatarstan, although in 1965 one breeding pair was found in the Kama $\mathrm{R}$ flood-plain in Rybno-Slobodskiy district (Sotnikov 1999).

Spring migrants begin to pass through the Kirov and Tatarstan regions before the river ice breaks up forcing the birds to rest on polynias ${ }^{5}$ during early April and continue to do so throughout April, with mature birds moving through very quickly and first year birds passing through later and sometimes remaining until mid May (Sotnikov 1999). Return migration begins as early as mid September, but by the end of October all have left as waters freeze over, although occasionally individuals have wintered on lake or river polynias most probably because they were injured or diseased.

Sotnikov (1999) considered that Whooper Swans have few natural enemies, and that man has the greatest influence. They are occasionally shot in mistake for geese at dusk; they have been reported dying in collision with electric transmission lines, and during the 1940s and 1950s the drainage of the majority of windmill ponds where they used to breed seriously affected them in this region. The sharp fall in the Whooper Swan population at the end of the $19^{\text {th }}$ and beginning of the $20^{\text {th }}$ centuries was apparently related to considerable over-exploitation of them on the Caspian Sea and other places during the moult, with as many as 300 birds killed per boat in a day. Now, despite being protected, the absence of breeding habitat prevents their return.

In the Volga-Kama $R$ area of central western Russia ${ }^{6}$, during the middle of the $19^{\text {th }}$ century, the Whooper Swan used to be a common migrant and winter visitor with some breeding at large ponds and lakes. In particular it was considered quite a common bird of the Middle Volga and Kama rivers, and also bred on the Sura, Usa, Mesha, Belaya, Iku, and Bolshoi Cheremshan rivers (E. A. Eversman 1866, M. Bogdanov 1871, both cited in Artem'yev \& Popov 1977). By the late $19^{\text {th }}$ century, however, its range was already

${ }^{5}$ Polynia, though often used in a strictly oceanographic sense, means an area of open water otherwise surrounded by ice. It may remain ice-free for various reasons including the presence of upwellings or currents, but its availability is important to wildlife.

6 The central portion of the huge region situated to the east of Moscow and stretching north from the Caspian Sea towards the Barents Sea. 
contracting so that it then bred only on the Mesha, Vyatka, Volga, and Kama rivers (M. Ruzskiy 1893 in Artem'yev \& Popov 1977). The species certainly continued to breed in the region until 1926, when two young were trapped for Kazan Zoo. Between then and 1965, however, there were no certain breeding records. A pair was recorded in summer 1935 (19 June) in the Kai district of the Kirov Oblast; then in 1965 a pair bred, once again in the Kama $\mathbf{R}$ flood plain in the region of Rybnaya Sloboda village (Artem'yev \& Popov 1977).

In spite of annual observations in the region, Artem'yev \& Popov (1977) were able to find Whooper Swans only in 1956, 1959 and 1960 during spring migration in April, and once during autumn on 24 October 1959, indicating that, although it was a common species over a century ago, it is now only a rare visitor to the Volga-Kama region.

In the Republic of Mordovia, which lies between Gor'kiy and Penza at approximately $55^{\circ} \mathrm{N} ; 45^{\circ} \mathrm{E}$, the Whooper Swan is currently rare on migration, although it was apparently commoner during the period $1900-1920$. It also bred in the area in the $19^{\text {th }}$ century, but has not done so since (Lysenko et al. 1997). At similar latitudes to the east of Mordovia and the Volga, in the Ul'yanovsk Region lying between Kuibyshev (now Samara) and Kazan, the Whooper Swan used to nest during the second half of the $19^{\text {th }}$ century, in the valleys of the larger rivers. Now, however, they occur uncommonly and even then only on migration, more often along the Volga R valley. In 1995, 1997 and 1998, however, 24 Whooper Swans summered on Staromainskiy Bay of Kuybyshev Reservoir (Kuybyshevskoye Reservoir) (Barabashin et al. 2001).

In the Kuibyshev region itself, Gorelov et al. (1987) noted that although Whooper Swans were more widely recorded in the $19^{\text {th }}$ century, anthropogenic pressure during the early part of the $20^{\text {th }}$ century led to its decline in the Kuibyshev Oblast. Nevertheless, during the 1970s and 1980s they occasionally appeared on isolated steppe lakes and old riverbeds in the Bolshe-Chernigovskiy and Khvorostyanskiy districts, and from 1970 onwards two pairs bred successfully in the Avgustovskiy Game Reserve (GR), increasing to six pairs in 1977. In 1979, two pairs were also recorded in the Rostashinskiy GR (both game reserves are in Bolshe-Chernigovskiy District). In Khvorostyanskiy District in 1971 a pair nested at the Chagra R; in June 1977 a pair of Whooper Swans was found nesting on a small lake near Abashevo, and later the same month two more breeding pairs were discovered nearby (Gorelov et al. 1987). These and several other summering records indicate that the Whooper Swan may be re-colonising this area.

In the nearby Mari Territory, previously known as Cheremisskiy Territory, which lies in the area northeast of Mordovia and northwest of Orenburg, swan numbers were so high in the $16^{\text {th }}$ and $17^{\text {th }}$ centuries that hunting them was of commercial significance. Since then, however, swan numbers have fallen until they were extirpated in 1919. Then, in June 1976, eight swans were seen on Palenoe L, and in July 1977 eight birds visited fishponds near Joshkar-Ola. In subsequent years pairs and small groups of up to 11-15 Whooper Swans have occurred on various water bodies in the republic, staying throughout the spring and summer period. Then, in 1983, a pair bred for the first time in Mari ASSR at the shallow Cheboksary Reservoir. In the years following, the number of breeding pairs increased until by the late 1980 s there were about 50 adults summering, among which 8 - 
9 pairs bred (Baldaev 1990).

In the Ryazan Region (its capital at $54^{\circ} \mathrm{N}, 38^{\circ} \mathrm{E}$ ) south of Moscow, the Whooper Swan used to breed in small numbers until the 1960s, otherwise it is a scarce migrant during the period from early April to early May in spring and from early October to early November in autumn (Kotyukov 1990). To the south of the Ryazan Region, in the Tula Region, the Whooper Swan sometimes used to nest on lakes of the northern part of the region, and also occurred on migration. From 1879 onwards for nearly a century, however, the Whooper Swan was not referred to in any literature for the Tula Region. Then in 1956, and several times subsequently during the 1980s, they have been seen again on migration (Miller \& Skalon 1990).

In the extreme southwest of the Western Russian region, in the Don $\mathrm{R}$ region, lying just east of Ukraine, spanning the Don $R$ which ultimately flows into the Azov Sea at Rostov-na-Donu $\left(47^{\circ} \mathrm{N} ; 39^{\circ} \mathrm{E}\right)$, the Whooper Swan is an uncommon migrant that uses the Lower Don $\mathbf{R}$ valley as its migratory route. It is considerably less numerous than the Mute Swan, occurring occasionally in spring, and then only in small numbers during mid-March and early April, and is even scarcer in autumn. Nevertheless, there have been occasional winter records (for example in January 1988 along the lower Don R), but during winter its numbers are unstable and subject to sharp fluctuations at most of the sites where it occurs. It has even been recorded as a scarce breeding bird. Two pairs of Whooper Swans bred at the thermal sedimentation ponds of the Novolipetsk Metallurgic Plant (with an area of 200 ha) in 1981, and pairs have attempted to breed at large ponds and fish farms in the Lipetsk and Voronezh Regions, however such cases were rare and not annual, and with poaching ending some attempts (Belik 1990, Sarychev et al. 1990). More recently in the Lipetsk and Voronezh regions, Klimov et al. (2001) regarded it as a rare passage and breeding species with 10-15 pairs remaining to breed.

In the region lying between the Volga and Ural rivers (south of Kuibyshev and north of the Caspian Sea), the Whooper Swan has bred, but is commoner as a passage migrant (Shevchenko et al. 1993). For example, pairs nested in 1966 (2 eggs) and in 1969 (7 eggs) on the Kamysh-Samarskie lakes, and a pair with cygnets was seen in early July 1970 on Ak-Kul' $L$ by the Lower Uil R. Individuals have also occurred in summer in the region, on the Kisyk-Kamysh L in the Lower Kushum R in summer 1967 and on the Bolshoi Uzen' $R$ in 1961. Small numbers of migrants (in flocks of up to 42 birds) have been seen passing through the Volga-Kama sands in late March (as early as 24 March in the Gur'yev Region), early and late April, and late May, and again in autumn between 10 and 28 October (Shevchenko et al. 1993).

Similarly in the Orenburg Region straddling the middle and upper reaches of the Ural $\mathbf{R}$, an area of steppe belonging to Trans-Uralia, but still west of the Urals, the Whooper Swan is most visible during spring migration during late March and throughout April when flocks of up to 60 occur in the area surrounding Orenburg and in the Trans-Uralian steppe (Samigullin 1990). The Whooper Swan is recorded as having bred in the Orenburg Region in the latter half of the $19^{\text {th }}$ Century. Since then, however, it had only been reported on migration until May 1995, when it was again found breeding in Orenburg, this time at Malyi Obalykol L in the Svetlinskiy district. The nest was set amongst reeds on an 
occupied Muskrat den (a fairly common nest situation in Russia) about $25 \mathrm{~m}$ from open water (Kornev \& Korshikov 1995).

In the southern part of the Western Russian region, in the Volga $R$ delta in the northern part of the Caspian Sea, the Whooper Swan is a very common migrant and a common winter visitor from October until April, with numbers stable in recent years (Rusanov 1990; Rusanov et al. 1999). Whooper Swans form mass concentrations there each winter along the western part of the delta where the Volga reaches the Caspian $\left(46^{\circ} \mathrm{N} ; 48^{\circ} \mathrm{E}\right)$. They particularly favour areas with Lotus Nelumbo nucifera, whose seeds and roots they are particularly fond of. In the Damchik (skiy) area of the Astrakhan NR, where lotus thickets cover an area of about 3,000 ha, concentrations of Whooper Swans in late October and during November have reached 10,000-30,000 (Rusanov 1990).

Rusanov (1987), who studied the northern Caspian Sea region, identified three important areas for wintering swans: the shallow-water delta of the Volga $\mathbf{R}$ out to a depth of two metres in the northern Caspian (some one million hectares); the Kizlyar region, and the region of the Kulaly and Morskoi islands.

Because low winter temperatures cause the delta and northern Caspian to freeze over for much of the winter, swans mainly winter in the microhabitats offered by patches of ice-free water on the channels and sea, mostly in the southwest portion of the delta region. The Kizlyar wintering region consists of Kizlyar Bay and the coastal zone of the Caspian north of the delta, and south to Chechen Island and the northern part of Agrakhan (skiy) Gulf amounting to some 433,000 ha. This region is also mostly shallow $(<1 \mathrm{~m})$ although in the region of Tyuleniy Island depths reach $2 \mathrm{~m}$, and to the east of it they reach 5-6 m. The lowland coastal belt here consists of thickets of Phragmites australis, Typha angustifolia and Typha laxmanni, Aster sp. and Scirpus lacustris. Winter temperatures are also low here with ice-cover lasting on average 66 days from late December until late February. Winds help keep some areas ice-free allowing birds access to submerged vegetation such as Potamogeton, and Zostera. In the region of the Kulaly, Morskoi, and Rybachiy islands water salinity is very high, averaging $10.9-11.2 \%$, emergent vegetation is absent, and submerged vegetation consists mainly of Potamogeton pectinatus, Zostera spp., Arabis spp., and Ruppia spp. Winter air temperatures here are somewhat lower than near the western shore of the northern Caspian Sea, and ice cover remains on average 67 days from the end of December until the beginning of March. Strong easterly winds dominate and keep large areas ice-free. The numbers of swans found wintering in these three regions is related to winter weather conditions with fewer birds in colder winters. When wintering conditions worsen suddenly, the swans leave the Volga R Delta region moving to the Kizlyar region or even further to the shores of Dagestan, Azerbaijan and Iran (Rusanov 1987).

Large concentrations of swans occur off the mouths of various of the channels of the Volga $\mathbf{R}$, with numbers ranging from several hundred to several thousand birds (19551969), and with as many as 33,200 wintering in the Kizlyar region in 1980 (although the average there was of 7,300). In mild winters more birds remain in the Volga delta area and numbers are fewer in the Kizlyar Gulf (Rusanov 1987).

The most remote and hence least studied wintering region is the open water near Kulaly, Morskoi, and Rybachiy islands, in the eastern part of the northern Caspian Sea. 
Here too swan numbers reached their highest levels during mild winters in the 1970 s (5,000-10,500) (Rusanov 1987).

In addition to these three main regions, in some winters Whooper Swans have been seen on the open sea near the ice edge in areas where Caspian Seals Phoca caspica concentrate to give birth. Sightings in such areas were more frequent in severe winters, and at such times the swans may easily cross from one shore to the other of the Caspian Sea and hence from one country to another.

The northern Caspian Sea is an area of mass wintering and in both 1976 and 1980 the number of swans exceeded 30,000, although some Mute Swans may have been included. Average winter numbers for 1970-1980 $(13,900)$ greatly exceeded the numbers recorded for 1955-1969 (1,850), perhaps as a result of the hunting ban in place since 1956, and as a result of wintering numbers decreasing on the South-Caspian Sea wintering grounds (Rusanov 1987).

Studies on family size in the Damchik (skiy) area of the Astrakhan NR during October and November 1981-1987, found that broods range in size from 1 to 8 cygnets, but that the most frequent brood sizes are of three and four. As seen elsewhere, the average brood size varies from year to year, from 3.13 to 4.03 chicks in this particular region, with the lowest average brood sizes in the severe winters of 1982 and 1985 . In these years, weather conditions on the wintering grounds were so bad that some even died. Not only does brood size decrease, but so too does the number of broods. Fewer broods are recorded in autumn concentrations of Whooper Swan migrants in the Volga delta in years with hard conditions on the wintering grounds (Rusanov 1990).

\section{Western Siberia, from the Ural Mountains east to the Yenisei River}

As one travels eastwards, first from Western Europe to Western Russia, then across the Ural Mountains and further east into Siberia, the Whooper Swan's range expands dramatically but, in contrast, the number of swan biologists becomes fewer and the amount of information available becomes considerably smaller. Population sizes are difficult to assess in this region as access on the ground is so difficult and from the air so expensive, and information is sometimes contradictory, making it difficult to draw overall conclusions.

\section{Trans-Uralia}

In the steppes of the Southern Urals, research on Whooper Swans was conducted between 1968 and 1995 in the Orenburg Region (see Fig. 3). There, in spring, Whooper Swans appeared in small flocks of up to 60 birds from about 20 March onwards. From then onwards they appeared in the middle reaches of the Ilek R (between the Novoodesskiy and Yaisan settlements in the Aktyubinsk Region), on the middle reaches of the Ural $\mathbf{R}$ (between the towns of Orenburg and Orsk), and on the Sarinskiy, and Ural-Tobol plateaux (Samigullin \& Parasich 1995). Migration continues throughout April and until about 20 May, with the general direction of migration being northeasterly. At this time, migrant flocks sometimes rest for periods of one to three days. Samigullin \& Parasich (1995) have reported as many as 700 swans at one time on lakes of the Ural-Tobol plateau, 


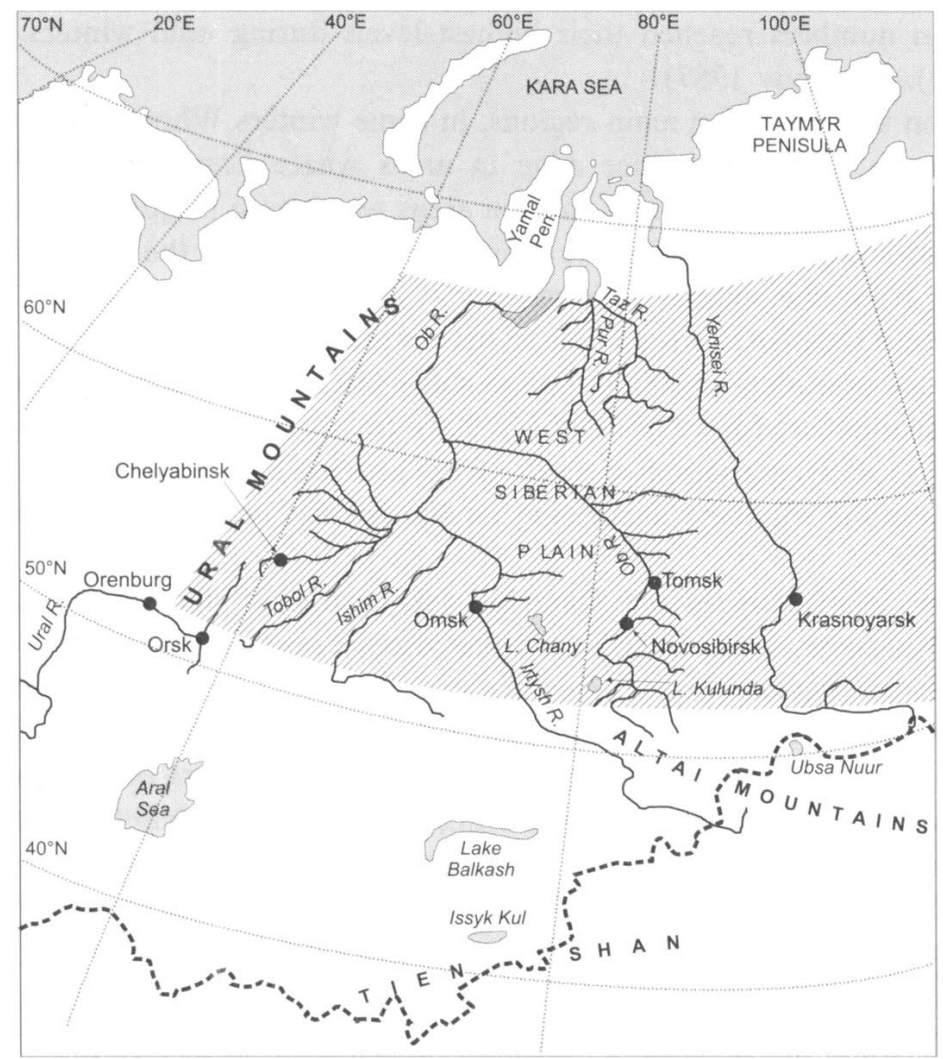

Fig. 3. Western Siberia showing the main locations mentioned in the text and the approximate breeding area of Cygnus cygnus.

however, both Whooper and Mute swans were involved, and their relative proportions were not noted.

Since 1992, Samigullin \& Parasich (1995) have also found Whooper Swans breeding on lakes of the Ural-Tobol plateau, with four nests and five broods found from 1992-1994 on Aike, Davlenkul, Kairankol, Karashakol, Obalykol, and Shalkar-Ega-Kara lakes in the Svetlinskiy district $\left(54^{\circ} \mathrm{N} ; 64^{\circ} \mathrm{E}\right)$. As is typical in other parts of their range, Whooper Swan pairs breed separately at shallow-water sites, building their nests amid reed beds or Typha thickets, and using reeds, Typha, and sedges as nesting materials. One nest was found on "splavina" (old floating vegetation), another was on a Muskrat den, and two were built up from the lake bottom. Samigullin \& Parasich (1995) have estimated that 59 pairs of Whooper Swans breed annually on lakes on the Ural-Tobol plateau. Clutches of 3-5 eggs are completed between mid-May and mid-June, with 2-5 cygnets hatching between late June and late July in this region.

The autumn migration of Whooper Swans takes place through the Ural-Tobol plateau from early October until mid-November, with the main passage being southwesterly. The peak of migration occurs in the first half of October when they occur in flocks of up to 200 
on the Iriklinskoe reservoir. The largest mixed concentrations of Mute and Whooper swans occur in mid-October on lakes on the Ural-Tobol plateau, when up to 1,000 birds occur sinultaneously (Samigullin \& Parasich 1995).

The timing of the Whooper Swan migration varies from year to year but, in autumn, it seems to be driven by sharp falls in temperature and in particular the fall of daytime temperatures from $5^{\circ} \mathrm{C}$ to $0^{\circ} \mathrm{C}$. Between 1979 and 1994 , analysis of flock structure revealed that $41 \%$ of migrant flocks consisted of fewer than 10 birds, flocks of 11 to 20 birds made up $32.3 \%, 21$ to 50 birds $18.6 \%$, and from 50 to 1,000 birds $6.1 \%$ of flocks. Surveys made during mid-October from 1983 to 1987 indicated that $67 \%$ of the swans passing through this region are Whooper, and 33\% Mute Swans (Samigullin \& Parasich 1995).

The Whooper Swan is a common migrant through southern trans-Uralia (Samigullin 1990, Gordienko 2001). On migration during both spring and autumn, Whooper Swans are usually encountered in flocks of $20-50$ birds (48\% of observations), often forming mixed flocks with both Mute and Bewick's swans and forming concentrations of up to 1,000 or more. The majority of the migrant Whooper Swans passes through the Chelyabinsk Region $\left(55^{\circ} \mathrm{N} ; 62^{\circ} \mathrm{E}\right)$ before the main passage of Mute Swans. The largest flocks were found on the lakes of the forest-steppe of Trans-Uralia with maxima of 316 at Kurlady in October 1992, and about 500 there in October 1994, 349 at Tishki in October 1993, 130 at Sinara in April 1994 and smaller numbers (fewer than 60 each) at Okunkul' L Shabalish, Irtyash, Uvil'dy and Argazinskoe. The total number passing through the region on migration is estimated to range from 5,000-7,500 each year (6,200 on average) (Karyakin \& Kozlov 1999).

In the $19^{\text {th }}$ century the Whooper Swan was quite common on lakes in the north part of the Chelyabinsk Region, and even at the beginning of the $20^{\text {th }}$ century it still nested at several places in the Il'men NR for example, although it was declining and by the 1930s and 1940s only summering and migrant birds were observed. Then in the 1980s and 1990s it began to re-appear as a scarce breeding bird of the forest-steppe at the southern limit of its breeding range, with breeding occurring at 18 lakes in the region, three in the eastern Urals (Kundravinskoe L, Argazinskoe Reservoir, and Irtyash L) and the other 15 in the forest-steppe of Trans-Uralia (Karyakin \& Kozlov 1999, Gordienko 2001). In addition it also breeds on Travyanoe L (Oktyabrskiy district) (2 pairs) and also occurs on various other water bodies not investigated by Karyakin \& Kozlov (1999). The total number of pairs estimated as breeding in the region is $60-90$, with a further $50-120$ non-breeders.

In the Kurgan Oblast (east of Chelyabinsk and to the west of Omsk and its capital is situated at approximately $56^{\circ} \mathrm{N}, 66^{\circ} \mathrm{E}$ ), Braude (1998), who conducted swan surveys in August 1989 and 1998 of lakes in the Lebyazh'yevskiy, Makushinskiy and Chastoozernyi districts in the eastern part of Kurgan Oblast, found that swan numbers were considerably greater in 1998 than in 1989, with 6,832 (Mute and Whooper in 1998) as opposed to 1,916 in 1989. Whereas in 1989 only four pairs of Whoopers were found, in 199856 pairs of Whooper Swans with broods were found; further investigation indicated that swans had increased throughout the Kurgan Oblast (Braude 1998).

In Trans-Uralia, the region lying immediately to the east of the Ural Mountains, the 
Whooper Swan is a common breeding species at lakes in the northern forest-steppe. In the southern part of Trans-Uralia it is an early spring migrant with birds arriving before the end of March and in early April once daytime air temperatures rise above freezing, despite water bodies still being ice-covered (Blinova \& Blinov 1997). The local forest-steppe population arrives early, in the first half of April, when they occupy lakes at a density of up to $0.1-0.2$ birds $/ \mathrm{km}^{2}$.

The heaviest migration takes place during the second half of April along the Tobol $\mathrm{R}$ valley when they are numerous (up to $47 \mathrm{birds} / \mathrm{km}^{2}$ ) on the shallow saline lakes, on temporary floods of melting waters, amid fields, and on flooded water-meadows (Blinova \& Blinov 1997).

In the region of the Tobol $\mathrm{R}$, in spring, Whooper Swans migrate northwards $(65 \%$ of birds) or to the northeast $(35 \%)$. As in other parts of the range on spring migration, many of them travel in pairs (40\% of records). They occur here slightly less often in flocks of 20 to 50 birds (36\%), and more rarely in small flocks of from 3 to 10 birds (24\%), perhaps comprising the families from the previous year, and just $4 \%$ were found to migrate alone (Blinova \& Blinov 1997). Further investigation in this region might show that, as further west in Europe, the migration may occur in two waves, of potential breeders and non-breeders. The majority of the migrants have passed through by the end of April, although small groups may still be found in May on the inter-stream lakes of the northern forest-steppe at densities of up to $11 \mathrm{birds} / \mathrm{km}^{2}$ (Blinova \& Blinov 1997).

While Blinova \& Blinov (1997) consider that the Whooper Swan breeds at a high density in the northern forest-steppe between the Tobol and Ishim rivers east of Chelyabinsk, it has not been found breeding in the southern forest-steppe and it is certainly rare further to the south in the steppe zone of Kazakstan. Their description of the Whooper Swan's breeding habitat includes shallow overgrown lakes and "water-meadows", where they occur at average densities of three or four individuals $/ \mathrm{km}^{2}$ during the first half of the summer. Although they also occur on lakes outside the Tobol R valley, breeding there has not been confirmed. As elsewhere, Whooper Swans appear on the steppe zone towards the end of March and during the beginning of April, and there they breed on isolated lakes (Blinova \& Blinov 1997).

Departure of Whooper Swans from their forest-steppe breeding grounds begins during the first half of September, when they begin to appear on large freshwater lakes in the southern forest-steppe between the Tobol and Ishim rivers. The migration continues throughout September and early October with flocks of swans seen in flight across the whole landscape, with some flocks halting at open flood-land lakes of the southern Tobol $\mathrm{R}$ valley while others visit slightly saline lakes on the plains between the rivers (Blinova \& Blinov 1997).

During the autumn migration, the majority of flocks consists of 11-60 birds ( $68 \%$ of groups). Fewer birds (23\%) travel in small flocks of from 3 to 10 birds, which presumably represent the new family parties, and more rarely they are found travelling alone $(9 \%)$. In contrast with observations made during spring, pairs were not observed during the autumn migration. At this time of year the majority of swans (80\%) fly southwards and the remainder chiefly southwest (19\%) (Blinova \& Blinov 1997). 
In Middle Trans-Uralia in the region of Tyumen, within the borders of the middle taiga of Western Siberia, Antipov (2001b) made aerial surveys of the Whooper Swan population. This region consists of forest, swamp, lakes, and rivers, providing ample habitat for the species. Of the 2,620 swans counted over seven years, the majority were found along in the Konda $\mathrm{R}$ basin (along the left bank of that river) with about half-in the "Elizarovskiy" Federal GR. Densities ranged from $0.01 \mathrm{birds} / \mathrm{km}^{2}$ in some swamp habitats, to $0.17 / \mathrm{km}^{2}$ in flood-land habitats of the $\mathrm{Ob} \mathrm{R}$.

The past status of the Whooper Swan and Mute Swan in the Omsk Region spanning the Irtysh $\mathbf{R}$ drainage, has been poorly described. Furthermore, some of what has been published seems misleading and pertains only to the latter part of the $19^{\text {th }}$ century. Contradictory statements appearing in different papers make the issue even more confusing, thus I. Ya. Slovtsov in one paper indicates that the Whooper Swan is a common species in the region by referring to "...extensive flocks of Whooper Swans in the south of the Tyukalinskiy district", whereas in another paper he describes the Whooper Swan as rare during the breeding season and common only on passage. Furthermore, whereas Slovtsov considered that the Mute Swan was a rare vagrant in the region, at the same time M. Morozov recorded both Mute and Whooper Swans as common on lakes of the steppe zone (Slovtsov 1892, 1897, Morozov 1898 all cited in Yakimenko 1997), suggesting that confusion over identity may have been adding to difficulties in agreeing over status.

A recent 15-year study by Yakimenko has helped clarify the current status of both species of swan in the enormous Omsk region. The Whooper Swan is still a migrant through the Omsk region and it also breeds commonly in the steppe, forest-steppe and within the southern taiga forest. The Mute Swan also breeds in the region, principally in the southern forest-steppe and steppe north to the latitude of Omsk City $\left(55^{\circ} 00^{\prime} \mathrm{N}\right.$; $73^{\circ} 30^{\prime}$ E) (Yakimenko 1997).

The Omsk Region covers a wide range of habitat including the southern taiga, northern forest-steppe, southern forest-steppe, and true steppe. The steppe and forest steppe zones are inter-cut with rivers and streams and have many lakes, while the taiga zone has many bogs, swamps, and lakes. The region also includes many brackish and highly saline lakes. Thus in the Omsk Region both Whooper and Mute swans are found on brackish or slightly mineralised lakes (Yakimenko 1997).

In the northern forest-steppe, spring migration begins during the last third of March and continues until about 20 April, although the dates vary somewhat from year to year. In the central forest-steppe, in the vicinity of Omsk itself, their movements occur up to 10 days earlier. Whooper Swans heading further north continue to migrate into the second half of May, even into the beginning of June, by which time local birds are already incubating (Yakimenko 1997).

Certain lakes in the region are particularly attractive to waterfowl and shorebirds, and concentrations of Whooper Swans also occur there on migration. For example, the Solenoe, and Gorkoe lakes (in Tyukalinskiy and Krutinskiy districts, respectively) are shallow, highly mineralised lakes in the northern forest-steppe. They warm up rapidly in spring, consequently submerged vegetation develops early, such that by May the lakes are already highly productive. At the same time, above-water vegetation is still absent, so 
waterfowl find food plentiful within the lakes and the lakes secure. Both Anseriformes and Charadriiformes concentrate in their thousands on lakes such as these during the second half of May and even in the first third of June, although the Whooper Swans leave the lakes, as a rule, by the end of May except in springs with unfavourable weather conditions when they remain even longer. So for example, in 1996, when cold weather with snow continued until the end of May, more than 400 swans remained on Solenoe $L$ until about the 10th of June (Yakimenko 1997).

In autumn, Whooper Swans begin to leave the northern forest-steppe between 20 September and 15 October. They fly in a southerly direction at a height of from 100 to 400 metres. The flocks consist of several tens or even hundreds of birds. Small flocks stop to roost on lakes in the taiga zone and may remain at the same place for several days (Yakimenko 1997).

Estimation of the breeding population of the Omsk Region is made problematical by the difficulty of access to the huge number of lakes in the region that vary considerably not only in their size but also in their abiotic and biotic characteristics.

In the southern taiga, where oligotrophic sphagnum bogs are widespread, very few Whooper Swan pairs breed. Rather more occupy the deciduous forest zone at densities estimated at $0.8-1.0$ pairs $/ 100 \mathrm{~km}^{2}$. The estimated population of this habitat was $80-100$ pairs. The northern and central forest-steppes are the most densely and most evenly populated habitats of the Whooper Swan, with $0.4-2.0$ pairs $/ 100 \mathrm{~km}^{2}$ and as many as $270-$ 300 breeding pairs.

In the southern forest-steppe and the steppe, divided by the Irtysh $R$, and in the Kurumbel steppe on the east bank of the Irtysh, Whooper Swans occur at a density of 0.7 pairs $/ 100 \mathrm{~km}^{2}$. On the west bank two pairs probably bred at Lake Alabota, but none were found at other sites. The number of Whooper Swans breeding in this area is low for two reasons, first because highly saline lakes predominate and these are unsuitable for breeding, and secondly because much of the area has been developed for agriculture. As a result, the number of pairs breeding in these habitat types is not high - in the region of 50-60 pairs. In total then, Yakimenko (1997) considered there to be 400-600 breeding pairs of Whooper Swans in the whole of the Omsk Region.

In the Omsk Region, Whooper Swans prefer to nest on small lakes ( $<10 \mathrm{ha})$ bordered by deciduous forest or with dense thickets of vegetation, with bogs and swamps. Where they nest at larger bodies of water, they select dense reed-beds or nest on uninhabited muskrat dens. Their feeding territories may be on large water bodies situated as many as several kilometres away from their nesting territories (Yakimenko 1997).

East of Omsk, in the Chany and Baraba districts of the Novosibirsk Region, particularly in the area of the 120,000 ha Kirzinskiy State GR on the northern shore of the enormous Chany L, which is situated in the Baraba Lowland, the area is a typical forest-steppe landscape, with an abundance of natural water bodies of different sizes and types. In addition to Chany $\mathrm{L}$, there are about 60 other lakes in the region. During the period 1968-1979, Fedorov \& Khodkov (1987) found that the Whooper Swan was a common bird of the Barabinsk (Baraba) forest-steppe lakes, with breeding pairs on 12 water bodies within the Kirzinskiy State GR and also on two of the largest islands 
(Amel'kina Griva and Shuldikovo) in Chany L. They clearly prefer shallow lakes (not exceeding one metre in depth) rich in submerged and emergent vegetation. The first Whooper Swans arrive in spring as early as early April, when temperatures are still as low as minus $20^{\circ} \mathrm{C}$ and when snow still covers the ground and ice the lakes. Migration continues until the end of the second third of April. Nesting is followed by egg laying in early May, and cygnets hatching in early to mid-June and fledging in late August and early September. Non-breeding birds gather on Chany $\mathrm{L}$ with the largest concentration in Parshikha Bay. Later, families with broods arrive and join them. During the 1960s, apparently as many as 5,000-7,000 Whooper Swans gathered each autumn on Chany L, although during the 1970s within the game reserve numbers were no more than 100-130, and no more than 250 were reported from Parshikha Gulf (Fedorov \& Khodkov 1987).

\section{The West-Siberian Plain}

On the west-Siberian Plain, that immense span of habitat stretching east from the Ural Mountains towards the Yenisei in the East, and essentially the drainage basins of the $\mathrm{Ob}$ and Irtysh rivers and their tributaries, the Whooper Swan finds habitat plentiful. It is a common, widespread species occurring in flooded swamps of the forest-tundra at densities as high as $3 / \mathrm{km}^{2}$, although at considerably lower densities in simple flood-lands $\left(0.3 / \mathrm{km}^{2}\right)$ and in waterless valleys $\left(0.2 / \mathrm{km}^{2}\right)$. It is rarer along the rivers themselves, occurring at densities of only $0.6 / 5 \mathrm{~km}$ of river. If the forest-tundra zone is examined as a whole, even here it is rare on average occurring at $0.5 \mathrm{birds} / \mathrm{km}^{2}$ (Ravkin et al. 1990).

In the northern taiga, the Whooper Swan occurs at a far lower density on average than in the forest-tundra, although the extent of the habitat means that more birds actually occur in this type of habitat than in forest-tundra. Here it is commonest on lakes $\left(2 / \mathrm{km}^{2}\right)$, but much scarcer on lakes beyond riverine floodplains $\left(0.4 / \mathrm{km}^{2}\right)$, in flood plains $(0.04$ / $\left.\mathrm{km}^{2}\right)$, and in dry valleys without rivers $\left(0.005 / \mathrm{km}^{2}\right)$. Along the rivers of the northerntaiga it is as scarce as along forest-tundra rivers $(0.6 / 5 \mathrm{~km})$ (Ravkin et al. 1990).

In the middle taiga the Whooper Swan also occurs at a low density, with the highest densities found on lakes $\left(3 / \mathrm{km}^{2}\right)$, in other habitats it is scarce (in flood plains $0.1 / \mathrm{km}^{2}$ ) or very rare $(0.01-0.04)$. To the south, in the southern taiga it is extremely rare occurring at densities as low as $0.007 / \mathrm{km}^{2}$ and at $0.009 / \mathrm{km}^{2}$ in sub-taiga forests (Ravkin et al. 1990).

Considering the forest zone as a whole, Ravkin et al. (1990) found its density to be just $0.1 \mathrm{bird} / \mathrm{km}^{2}$. Nevertheless, the vastness of this type of habitat in this region led them to estimate that as many as 252,000 birds occupy the region, although in the second half of summer, when one expects numbers to be considerably higher, being swollen by young of the year, they only estimated a population of $58,000^{7}$. Overall, in the forest zone, Whooper Swan occurred at their highest densities on lakes $\left(2 / \mathrm{km}^{2}\right)$, but at a tenth of that level on bogs beyond river flood plains $\left(0.2 / \mathrm{km}^{2}\right)$, and at even lower densities in the flood

\footnotetext{
${ }^{7}$ Assessing the significance and validity of the figures given in some papers has been extremely difficult. We quote them here so that the reader may consider the various possibilities themselves. For those with the inclination, time and funding, clearly Russia is the place to focus on Whooper Swan research, so much remains to be clarified.
} 
plains $\left(0.07 / \mathrm{km}^{2}\right)$ and waterless valleys $\left(0.006 / \mathrm{km}^{2}\right)$. On the rivers of the forested zone the Whooper Swan is rare $(0.2 / 5 \mathrm{~km}$ of river $)$.

To the south of the taiga zone, the Whooper Swan's range extends out into the forest-steppe and even on to the steppe itself. In these habitats it occurs less abundantly on average than in the northern taiga and forest-tundra, but more commonly than in the southern taiga forest area. Ravkin et al. (1990) estimated the stock in the first half of summer in the forest-steppe zone of this region to be about 12,000 birds with a further 3,000 in the steppe, again, however, they considered figures in the second half of summer to be considerably lower $(2,000 \text { in the forest-steppe and } 2,000 \text { in the steppe })^{8}$. In these habitats, highest densities were found at lakes $\left(0.6 / \mathrm{km}^{2}\right)$ in the forest-steppe and bogs beyond flood plains in the forest-steppe $\left(0.3 / \mathrm{km}^{2}\right)$ and even higher densities at steppe lakes $\left(1 / \mathrm{km}^{2}\right)$ and at steppe bogs beyond flood plains $\left(0.6 / \mathrm{km}^{2}\right)$, while in river-less valleys they were very scarce $\left(0.02 / \mathrm{km}^{2}\right.$ in the forest-steppe and $0.0004 / \mathrm{km}^{2}$ in the steppe).

Considering the whole of the West Siberian plain, stretching from the forest-tundra in the north to the open steppe in the south, Ravkin et al. (1990) estimated that numbers in the first half of summer amounted to an astonishing 380,000 birds (at an average abundance of $0.1 / \mathrm{km}^{2}$ ), while in the second half of summer this figure was closer to 70,000 $\left(0.03 / \mathrm{km}^{2}\right)$, still an extremely large figure. The Whooper Swan is commonest on lakes, less common at swamps, scarce along rivers and rarest on flood-lands and in river-less valleys. Overall, the density and abundance of the Whooper Swan decrease from the northern forest-tundra southwards to the southern taiga, then it is slightly higher again in the forest-steppe, but lower again in the steppe.

On the West Siberian Plain, where Whooper Swans are widely distributed, recent surveys suggest a local population size that is several times larger than was previously estimated for the species as a whole (!) with an average of 10 Whooper Swans $/ 100 \mathrm{~km}^{2}$ in the first half of summer ${ }^{9}$. Total figures for this region are difficult to assess, some data is questionable, and Ravkin (1991), an important information source for the region, himself appears to give contradictory information. Ravkin says at one point that in Siberia the population is mainly concentrated in the northern taiga, but also that the highest density was in the forest-tundra with slightly lower densities in northern and especially middle taiga, and considerably lower densities in other habitats such as the steppe. Ravkin (1991) found, for example, that the largest numbers were in the northern taiga, mainly on large lakes $\left(2 / \mathrm{km}^{2}\right)$ or in small numbers on rivers $(0.2 / 5 \mathrm{~km}$ of river $)$. Far smaller numbers were found at waterlogged bogs $\left(0.2 / \mathrm{km}^{2}\right)$ and in flood basins and marshes $(0.1$ and $0.003 / \mathrm{km}^{2}$ respectively).

Further information from the 'West Siberian' region perhaps only confuses the issue more. Vartapetov (1984) observed Whoopers on a large lake in a peat bog, and on

${ }^{8}$ What is not clear from Ravkin et al.'s (1990) work is whether the high "first half of summer numbers" included very large numbers of spring migrants or not, although this seems the only reasonable explanation for the considerable drop to "second half of summer" numbers.

9 Why numbers should drop so dramatically from early to late summer is difficult to assess and not explained by Ravkin et al. (1990) though perhaps their early figures were over-inflated by large-scale migration through their area. 
meadows-pastures amongst sub-taiga forest at densities as low as $0.02 / \mathrm{km}^{2}$. He reported that whereas it is an extremely rare bird of marginal sub-zones of taiga inter-stream areas, it was by contrast observed considerably more often in the $\mathrm{Ob} \mathrm{R}$ valley. He concluded, however, that everywhere the Whooper Swan is rare or extremely rare. Could the situation really have changed so much for the better between 1984 and 1991 ?

The vast expanse of forest tundra and taiga and the many pools there no doubt provide ample habitat for an enormous number of Whoopers, but the total of 316,000 supposedly counted, and 380,000 birds estimated, just on the West Siberian plain during the first half of summer by Ravkin et al. (1990) and Ravkin (1991) does beggar belief, being more than three times the previous estimate for the entire Whooper Swan population (Brazil 1981, Madge \& Burn 1988), especially given that he found only 67,000 (estimated $70,000)$ in the second half of the same summer when one might expect numbers to be inflated by the addition of young of the year. Because the totals are based on sampling and extrapolation, however, the overall degree of error was accepted to be very large and the $95 \%$ confidence limits amounted to a range of 151,000-662,000 birds (Ravkin 1991). Nevertheless, even the lower end of that range means that Ravkin's (1991) West Siberian Plain population was considerably larger than previously estimated and, if at all accurate, requires that the total world population is very much larger.

Early in the year, particularly during the period from mid-May to June, Whoopers are extremely active and vocal, making them far more readily observed, and it was during this period that Ravkin made his earlier estimates, which he, too, considered may have been inflated. Taking all the possible reasons for overestimation into account Ravkin (1991) lowered his estimated population total by $45 \%$ to 173,800 individuals $(95 \%$ confidence limits $83,000-364,000$ birds). This is still a very large figure, even at its lower limits. There is a further complication. During the second half of June swan activity drops as non-breeders, which according to Ravkin (1991) comprise about $75 \%$ of the population, fly to remote lakes that were not censused, thus the counts might possibly be underestimates! With so much confusion, anyone's estimates of the population of this enormous region remain essentially guesstimates. Taking into account the figures further west, and the likelihood of swans occurring at higher densities in Siberia, a figure in the region of 100,000 birds for the West Siberian Plain population may well be reasonable, but even this requires that the world population of this species is considerably larger than previously estimated (Brazil 1981, Madge \& Burn 1988). Nevertheless, and in extreme contradiction to Ravkin's (1991) figures, the Western Siberian population has also been estimated at just 17,000 birds, wintering mainly in the Black Sea area, and regarded as probably declining (Scott \& Rose 1996).

Krivenko (1989, in Ravkin 1991) had made the only previous estimate of the same population, from 1971-1986 and had found the late summer population to be of just 52,000. That is still almost as large as the entire northwest European population. Interestingly, their late summer population estimates did not differ so markedly, and Ravkin considered it likely that Krivenko had underestimated. There is perhaps good reason to assume under-estimation, as Whooper Swans can be extremely wary when nesting and when rearing cygnets, retreating into thick vegetation where possible whenev- 
er there is indication of disturbance. Furthermore, during the period of the annual flightless moult Whooper Swans occupy remote, inaccessible, and undisturbed lakes and some may even leave for Kazakstan to the south in order to moult there. These behavioural traits make it inevitable that smaller numbers are likely to be observed later in the summer, particularly as many of the moulting sites were not censused.

Further north, aerial surveys made along the valley of the $\mathrm{Ob} \mathrm{R}$ (between Nefteyugansk and Khanty-Mansiyisk town; $61^{\circ} 24^{\prime} \mathrm{N} ; 70^{\circ} 20^{\prime} \mathrm{E}$ ) in relation to planned oil exploration confirmed Vartapetov's (1984) observations that they were commoner there than in the taiga inter-stream area. These surveys also revealed that Whooper Swans occur densely, though unevenly, throughout the $\mathrm{Ob} \mathrm{R}$ Valley area, with three or four broods observed just 100-150 m apart, an unusual concentration for the species. Furthermore, broods reared in the area were large (Poyarkov \& Johnson 1996). Of 64 broods in 1994 and 71 in 1995, numbers of cygnets ranged from 1-8, with two broods of eight found in September 1995. The average brood size in 1994 was 3.8, but 5.0 in 1995. An even higher average brood size of 5.3 cygnets $(n=34)$ has been reported from the Elizarovskiy NR situated in the $\mathrm{Ob} \mathrm{R}$ valley $\left(60^{\circ} 42^{\prime} \mathrm{N} ; 67^{\circ} 51^{\prime} \mathrm{E}\right)$, indicating that the $\mathrm{Ob} \mathrm{R}$ area provides particularly good breeding conditions for the species. Further observations in September 1995 of broods of nine and eleven cygnets together with an earlier observation of 14 cygnets in semi-natural conditions at the Askania-Nova Zoo indicate that Whooper Swans will at times either combine broods or that such large broods may originate from joint clutches. If that is the case for broods of 9 and 11 (Poyarkov \& Johnson 1996), it also raises the issue as to whether slightly smaller broods, such as those of seven or eight, are not also the result of joint clutches. Such brood amalgamation has been reported from the Bewick's Swan (Brazil 2002), and from the Trumpeter Swan in which $11.5 \%$ of broods were involved in amalgamation and, interestingly, brood amalgamation was coincident with high densities of breeding swans (Mitchell \& Rotella 1997). This would appear to be an area well worthy of investigation in the Whooper Swan. Also of note from Poyarkov \& Johnson's (1996) study, was yet further confirmation of considerable variation between years in breeding success in terms of brood sizes, with broods of two and three being most common (more than $20 \%$ each), but with broods of four and six also contributing more than $15 \%$ each of the total in 1994. In 1995, however, broods of one, two, and three cygnets were relatively scarce, whereas broods of four, five, six and seven were particularly common. Broods of four and seven each represented more than $15 \%$ of the total, and broods of five and six each contributed more than $20 \%$.

On the northern taiga of the West-Siberian Plain, the Whooper Swan is both a migrant and a breeding species but, although widely distributed, it is everywhere very rare according to Vartapetov (1998). Birds arrive along the Lower Ob R, from the beginning of April onwards, with migration continuing until mid May and with the most intensive movements occurring during the first half of May (Vartapetov 1998). In the Ob R valley in June Whooper Swans were observed at flood lakes and flooded channels and in flight over swamps and flooded areas. In the area around the Kazym $\mathrm{R}$ none were recorded from June to August, whereas in the Ob-Purov interstream area pairs and singles were observed on marshland lakes during the second half of June. In the area of the Tazov 
northern taiga, Whooper Swans were found along the Taz R only during the first half of June, though in the past they apparently nested in this region (Vartapetov 1998).

Aerial surveys of the Yamal-Nenets Autonomous District carried out in June-July 1977 and 1978 by Krivenko et al. (1984) found that highest nesting Whooper Swan densities were in the Ob $\mathbf{R}$ flood plain, at the Nadym $\mathbf{R}$ mouth, and along the east bank of the Nadym Ob. The population density was lower in the flood plains of the rivers Taz and Pur, and much lower in the rest of the area. Based on the extent of the aerial surveys and the available habitat, they estimated a population of up to 13,000 Whooper Swans summering in the area, with about 3,000 pairs breeding. They further estimated that the region would hold approximately 35,000 birds by autumn. The following year, the late spring, cold summer, and extraordinarily high water level in rivers, greatly affected numbers and dispersal of the Whooper Swan, leading to much lower numbers in the study area.

In the Yenisei $\mathbf{R}$ valley, which forms the eastern border to this second region, Whooper Swans occur during the breeding season at densities of $0.2 / \mathrm{km}^{2}$. On the basis of surveys over a number of years, Vartapetov (1998; in litt 2001) concluded that the highest density of Whooper Swans in the region is on wetlands and channels in the $\mathrm{Ob} R$ valley $(0.1 / 10 \mathrm{~km}$ of linear coast), with fewer in tussock swamps in combination with lakes on the plains, in the Yenisei $\mathbf{R}$ flood-plain and along the Taz $\mathbf{R}$ where the density was lower at $0.01-0.08 / \mathrm{km}^{2}$, while the lowest densities were in the flood-plain and swamps of the $\mathrm{Ob}$ $\mathrm{R}$ area $\left(0.004\right.$ and $\left.0.002 / \mathrm{km}^{2}\right)$.

On the whole, Whooper Swans in this region seem to prefer lakes within the flood plains of the Yenisei and $\mathrm{Ob}$ rivers and extensive marsh-lake complexes in the regions between the rivers. In the remainder of the region, where lakes are few, or the lakes are oligotrophic, the Whooper Swan is a far less common species (Vartapetov 1998). Trends through the summer are that single birds are sighted more often during June, while in July, although fewer birds are seen, these consist of breeding pairs, and none were seen in August (Vartapetov 1998).

The total population of Whooper Swans in the region is estimated from aerial surveys at 5,000 birds, with most $(60 \%)$ occurring on flood-plain swamps, fewer $(28 \%)$ on water bodies and least of all (12\%) on flooded areas (Krivenko et al. 1984, Vartapetov 1998). Estimating numbers in this region is extremely difficult as climatic conditions can alter the extent of the available habitat dramatically from year to year. Thus, for example, in the northern taiga in $1977,55,000$ birds were encountered, whereas in 1978 only 8,200 were found. Conditions varied considerably between the years with 1977 relatively warm and, with low water levels, the majority (79\%) of the Whooper Swans remained in the Ob R flood plain. In 1978, spring was later, the summer was cold, and high water levels were prolonged. As a result, larger numbers $(30 \%)$ remained in flooded areas and in the marsh-lake complexes of the inter-stream areas, and numbers were considerably higher than in 1977. In such years, when flood-plain habitats are less suitable for breeding, fewer pairs nest and the success of those that do breed is also reduced (Krivenko 1991, in Vartapetov 1998).

Along the west bank of the Yenisei $\mathbf{R}$ in Krasnoyarsk Territory, from the Kas $\mathbf{R}$ in 
the south to the upper parts of the Bolshaya Keta $\mathbf{R}$ in the north, is an area of relatively dense nesting of both Whooper Swans and Bean Goose Anser fabalis (middendorfi and/or johanseni). Here the Whooper Swan is widespread and nests at oligotrophic bog lakes of at least 25-30 ha in tundra areas and at mesotrophic taiga lakes (Zabelin 1996). Zabelin (1996) estimated that approximately 200-250 pairs of Whooper Swans bred in the Turukhansk region of Krasnoyarsk Territory during the early 1990s.

The $\mathrm{Ob} \mathbf{R}$ region north of Tomsk is an enormous area covering some 317,000 sq km, where five large rivers, the Tom, Chulym, Ket, Tym, and Vysyugan and a considerable number of smaller rivers, join the $\mathrm{Ob}$. The interlacing river systems and their floodplains with considerable swampy areas provides a wide range of wetland habitats suitable for various species of waterfowl including the Whooper Swan, which breeds throughout the area, including in the Elizarovskiy GR situated in the Lower Ob R flood plain (Vengerov $1990 \mathrm{~b})$. The population is considered rather stable there because surveys conducted in a limited study area were very similar in both 1963-1965 (900-1,000 individuals) and 19861987 (940-1,320) (Adam et al. 1990).

The Elizarovskiy Federal NR, a Ramsar Site, was surveyed during May, June August and September by Antipov (2001a). The distribution of birds in the flood-plain habitats was affected both by climatic and hydrologic conditions of the year. Thus in 1978, low temperatures and strong winds negatively affected swan numbers, as did high water levels in 1979. Swan densities after the breeding season were the lowest in these years, ranging from 0.2 to 0.48 birds $/ \mathrm{km}^{2}$ with the lowest densities from wetlands without sors ${ }^{10}$. In other, milder years, densities in the first half of summer ranged from 1.9 (1981) to 7.8 birds $/ \mathrm{km}^{2}$ (1979) and in the second half of summer from 2.1 (1982) to $4.8 / \mathrm{km}^{2}$ (1977). The Elizarovskiy NR is one of the main breeding and moulting grounds of the Whooper Swan in Western Siberia, and is significant at the international level. The average density of Whooper Swans within the reserve is apparently many times higher, than in equivalent habitats of the Middle and Lower Ob and Irtysh (Antipov 2001a).

Spring arrival is swift throughout the $\mathrm{Ob} \mathrm{R}$ region with birds appearing usually between 10 and 16 April in most years. The breeding density in suitable areas of habitat can be high, with for example one pair $/ \mathrm{km}^{2}$ in the flood plain of the Chernaya (situated between the $\mathrm{Ob}$ and Parabel' rivers) on 21 May 1987. Here the densely shrub-covered landscape hides innumerable channels and pools that provide protection and breeding habitat for the Whooper Swan (Adam et al. 1990).

Autumn migration takes place during mid-October seemingly almost simultaneously throughout the region with approximately $6,000-8,000$ passing through the $\mathrm{Ob} \mathrm{R}$ area in autumn, compared with about 4,000 in spring (Adam et al. 1990).

Hunting of the Whooper Swan in the Ob R area occurs, but is not common because of the tradition of protecting swans, and also perhaps because of the difficulty of hunting them, however, some are taken by poachers for their skins (Adam et al. 1990).

In the northern part of west-Siberia, the enormous $\mathrm{Ob} \mathrm{R}$, joined by the Irtysh at about

10 "Sors"-shallow, often saline swampy lakes in Kazakhstan and in the southern part of West Siberia, and also in the floodplains of large rivers; also shallow bays of lakes. 
$62^{\circ} \mathrm{N}$, drains northwards into the Obskaya Guba (as large as Lake Baikal) and hence into the Kara Sea. Vengerov (1990a) studied an area of approximately 76,600 sq km of the Ob $R$ drainage, a region strongly intersected by channels, with in between them innumerable lakes and flooded meadows-sors. The shoreline vegetation of these water bodies typically consists of sedges, but also sometimes Scirpus and reeds. In spring, the majority of the lakes are flooded by snowmelt and sors and large channels are flooded widely providing excellent feeding, nesting, and moulting and migratory resting sites.

While breeding pairs move through to the northern parts of this region to nest during April (and some in early May), moulting birds remain for the summer. The arrival of birds for moulting begins in the first third of May. At first these consist of solitary individuals, and small flocks of 3-5 birds, only later do larger groups appear or form. During the period from mid-May to early June, these flocks range in size from the low 20s to as many as 150 birds, although the largest group of all was of over 200 on 31 May 1987 (Vengerov 1990a). The movement of birds around the various possible moulting sites continues into mid-June, but the larger groups break down into pairs and small flocks of fewer than 10 birds scattered and hidden among the flood-land sors. Moult begins during early July with primary replacement of most birds occurring during this month. In 1987, the first birds to have already completed the moult and regained flying ability were seen on 7 August, and by the beginning of September all the adults had finished their wing moult. During the latter part of the summer they aggregate again and they remain together in areas rich in food until the time for their departure in autumn (Vengerov 1990a).

In the Elizarovskiy NR the number of moulting non-breeding Whooper Swans rose to more than 1,000 during the late 1980s. This increase was partly as a result of greater protection and reduced disturbance providing them with ideal conditions (hay-mowing was prohibited from 1986 and cattle pasturing from 1987). The large numbers of pairs found moulting there was thought to be indicative of immature pairs forming long before beginning breeding, combined with mature pairs that had lost clutches or did not breed for some reason (Vengerov 1990a).

\section{Altai Krai}

While the $\mathrm{Ob}$ flows for more than a $1,000 \mathrm{~km}$ north of Tomsk towards the enormous Obskaya Guba and the Arctic, to the south the topography is vastly different as one enters the Altayskiy Kray or Altai Krai (its the capital is Barnaul at approximately $53^{\circ} \mathrm{N}, 83^{\circ} \mathrm{E}$ ) where the Ob originates. The Whooper Swan, though rare in the Altai, does occur widely there too. It has been known of since at least the $19^{\text {th }}$ century at lakes in Gornyi Altai on Ukuk Plateau and on the Chuiskaya steppe. Whooper Swans even breed in southeastern Altai, particularly on the plains, at wetlands among the forested regions, at high mountain lakes. It breeds regularly on lakes in the Kulunda hollow in the inter-stream area between the Lower Kulunda R and the Suetka R, on Julu-Kul' L, and on lakes of the Kulu-Kul' hollow of the Altai NR. Small numbers also remain to winter in years when the weather is mild, for example at Teletsk $\mathbf{L}$ and along the upper part of the Biya $\mathbf{R}$ where these do not freeze completely (Kuchin 1988, Kuchin \& Kuchina 1990, Kuchin 2001b).

The Whooper Swan occurs at a low density in the Altai Krai, since as elsewhere it 
seems not to like its own company with even vast lakes usually inhabited by only one pair. In the eastern Altai it is rather rare, with widely scattered individual pairs. It only began to breed at the various lakes of the Kulunda steppe after the establishment of the Blagoveshchensk GR, where numbers increased slowly from one pair in 1978 to about 20 pairs by 1986 and 1987 (Kuchin \& Kuchina 1990).

In spring, they arrive quite early at breeding sites in the Altai Krai, even before most of the snow has melted and while the lakes are still frozen over. The first migrants have been reported as early as on 10 March 1962 on the Biya R (near Bijsk town). In the upper part of the Ob R, on Bolshoe Kamyshnoe L, the first Whooper Swans arrived on 12 March 1987. Despite the occasional early arrival, the main, mass migration occurs here during mid-April (Kuchin \& Kuchina 1990).

Although they usually arrive in pairs at the breeding sites, sometimes flocks of immature birds appear at lakes and some remain throughout the summer. Disturbance is a significant factor driving pairs away from lakes that they may occupy briefly in the spring. Where lakes are more remote or little visited, or where they are well grown with reeds, Whooper Swans are, however, able to breed. Thus for example in the area of the Kulunda hollow, during the first seven summers of the 1980s Whooper Swans nested on four different lakes around which cattle pasturing and various other activities occurred. Breeding output, however was not great. Eight known broods totalled 24 fledged cygnets with an average brood size of three.

Whooper Swans begin to migrate away from the Altai Krai in autumn from the end of September onwards and by mid-October they have all gone. On lakes in the Upper Ob $\mathbf{R}$ forests, they remain until consistently low temperatures lead to the formation of ice. So, for example, on Bolshoe Kamyshnoe $\mathrm{L}$ a flock of seven birds remained as late as 10 November in 1986, although in 1987 a flock of 24 birds was forced away by ice on 26 October (Kuchin \& Kuchina 1990).

The wintering areas of the birds that breed in the Altai are not yet known, although it is possible that some also winter in the Altai Krai. The coincidental timing of departure of birds from the lakes of the upper $\mathrm{Ob} \mathrm{R}$ forests, with their arrival at ice-free spring-fed lakes situated at lower altitude on the plain of the left bank of the lower Katun R, indicate this. Confirmation of this comes from the observations of local people who have noted that swans regularly winter on three non-freezing lakes (Lebedinoe, Svetloe, and Bezymyannoe) and on small rivers that flow out from these lakes. Over the 20 years from 1966 to 1986, arrival at wintering sites varied from the end of September (1966) to the first third of November (in several years), and it was usually consistent with the arrival of consistently low temperatures, deep snowfalls and ice on other lakes. During the same period, the number of swans on these lakes increased steadily from just 10 in 1967 to 35 in 1986. The increase is at least partly due to additional protection given to the area (as a game reserve) since the mid 1970s. The proportion of young present varies considerably. Among 316 birds counted over 15 winters, young amounted to 69 (22\%). The wintering numbers at these lakes continued to rise, to 98 in 1993, and to maxima of 253 in December 1996 and 232 on 30 December 1997, a steady increase, which seems attributable to changes in climatic conditions. In addition to these spring-fed sites used each winter, in 
mild winters small numbers of Whooper Swans also occur on Teletskoe $L$ and along the upper parts of the Biya R (Kuchin \& Kuchina 1990, Kuchin 2001a).

\section{Tuva and Khakassia}

To the east of the Altai is the Tuvan ASSR. In Tuva, the Whooper Swan was once a quite common bird breeding for example at Khadyn, Chagytai, and Jerjaryk lakes, and it also winters at Ubsu-Nur L (across the border in Mongolian Tuva). Unfortunately, it is declining in Tuva and in some places it has disappeared completely, breeding now only occurs in little-developed regions of eastern Tuva and on Ubsu-Nur L. The middle reaches of the slow-flowing Belin $\mathbf{R}$, with its great loops and meanders, swamps and reed thickets and former riverbeds provide(d) good habitat for waterfowl and Whooper Swans certainly bred here during the 1960s. Ubsu-Nur L is an important site that supports not only breeding pairs but also small flocks of non-breeding birds (Baranov 1990).

The Whooper Swan is a scarce bird on spring passage through Tuva, or at least rarely recorded and then only during late April and early May. In autumn, it is somewhat commoner with as many as 500 occurring in a season in some regions of Tuva (according to Savchenko et al. 1986, in Baranov 1990).

Emel'yanov \& Savchenko (1988) made aerial surveys of Tuva and adjacent Khakassia during the spring to autumn periods of 1980 to 1987 . They found that spring migration began in the south of the region from mid-April to early May with the arrival of the first birds dependent on the climatic character of the spring. Migration involved individuals, pairs and small flocks, and its timing coincided with the formation of the first ice-free open water patches on rivers and shallow lakes. Migrants pass through Tere-Khol $\mathrm{L}$ in southern Tuva, Khadyn $\mathrm{L}$ in central Tuva, and Ulukh-Kol and Bele lakes in Khakassia over a period of about 15 to 30 days.

In this region, Whooper Swans are most often seen at medium-sized and large water bodies west of the Yenisei $R$. The intensity of passage through this region is very low, with only small numbers of birds involved, although circumstantial evidence suggests that more may pass through Khadyn L in Tuva and Ulukh-Kol L in Khakassia at night. Ulukh-Kol supports the largest Whooper Swan concentrations in the southern part of Western Siberia in spring, with over 2,500 birds counted passing through during the period from 23 April to 9 May 1987, and with as many as 800 at one time; large numbers do not occur here in autumn because of the disturbance caused by considerable hunting. Most depart at night and early in the morning and head north and northeast (Emel'yanov \& Savchenko 1990).

The autumn migration of Whooper Swans through the south of Western Siberia begins in the first half of September and continues throughout September and the first third of October. In any given year, migration usually occurs in a single wave during a period lasting from 10 to 20 days. In Khakassia, the peak was during the first four days of October in 1986 (at Bele L and Ulukh-Kol L), and in Tuva it was from 7-10 October at Khadyn L and Tere-Khol L in 1980 and 1982). They are commonly seen in flocks of from 3 to 20 birds and on migration they prefer the more open steppe lakes as resting sites. After Ulukh-Kol, Bele L is the second most important wetland in the region with up to 370 Whooper Swans occurring in spring and up to 500 in autumn, and as many as 100 
occurring at one time.

\section{Conclusion}

Despite the considerable research effort on the Whooper Swan in Europe, especially in the northwest, the vast majority of the Whooper Swan's breeding range falls within the political boundary of modern Russia. The enormity of the region, combined with the small number of resident swan biologists, and the difficulty of access to most areas, has meant that for many areas even the most basic information is not available. Given the difficulties involved, it is impressive that so many papers have been published on this species in its Russian range in recent decades, yet so much remains to be learned from this enormous region.

The northern limit to the species's normal breeding range in Russia is between $66^{\circ} \mathrm{N}$ and $68^{\circ} \mathrm{N}$, although it has also bred north to $70^{\circ} \mathrm{N}$ and even $72^{\circ} \mathrm{N}$. Whereas it breeds south to approximately $62^{\circ} \mathrm{N}$ in the west, in the Russian Far East it can be found breeding as far south as $50^{\circ}-55^{\circ} \mathrm{N}$ (Brazil \& Shergalin in press). Its wintering range is also latitudinally variable, with birds in the west wintering as far south as $47^{\circ} \mathrm{N}$ to $50^{\circ} \mathrm{N}$ in the Caspian Sea area, Kazakhstan, Mongolia and China, although in Japan, for climatic reasons, it can be found wintering regularly as far south as from $35^{\circ} \mathrm{N}$ to $40^{\circ} \mathrm{N}$ (Brazil 1991). The breeding range in Russia includes a range of different habitats that include various types of wetlands (rivers, marshes, lakes) in: northern taiga forest, northern forest tundra, tundra (occasionally), southern taiga, forest-steppe, and steppe.

Whooper Swans breeding in western Russia, west of the Ural Mountains, and those breeding to the north of that mountain range, are presumed to migrate to winter in the east Mediterranean, and the Black Sea area. Those breeding in Western Siberia are presumed to winter to the south in, and possibly also including the region around, the Caspian Sea. Birds from the Central and Eastern Siberian regions may winter in Mongolia, China, and east Asia, while those breeding in the Russian Far East migrate to winter primarily in Kamchatka and Japan.

Population estimates remain highly speculative and there is a clear need for further investigation to clarify both the migratory movements from different regions and the sizes of populations breeding in particular regions. On the basis of estimates of wintering populations outside Russia, the numbers breeding in western Russia and Western Siberia may be as few as 10,000 or as many as 70,000 (Rees et al. 1997), although research in the area by Krivenko (1989, in Ravkin 1991) suggested a late summer population for the West Siberian Plain alone of 52,000 and Ravkin (1991) based on his surveys supposed there to be a very much larger population in that area, exceeding 100,000 birds. Figures from Central and Eastern Siberia are difficult to assess, but it seems likely that the population of the Russian Far East is in the region of 60,000 birds.

The breeding population within Russia is large, and may be expanding its range northwards. In some parts of its western Russian range it was reoccupying areas during the latter half of the $20^{\text {th }}$ century from which it had been eliminated earlier as a result of persecution, while in other areas it is losing habitat and its range is contracting as a result 
of habitat loss and disturbance during the breeding season.

Although the majority of the Whooper Swan's world population breeds in Russia, most of these birds migrate to areas beyond Russian borders to winter in adjacent countries, around the Baltic Sea, the Caspian Sea, and the Sea of Japan. As a migratory species, the Whooper Swan is therefore the responsibility of a large number of countries, nevertheless as the host of the majority of breeding Whooper Swans it is Russia that shoulders the greatest responsibility for maintaining the non-endangered status of this species. That said, current research on the species is strongly biased towards activities in the extreme western and eastern parts of the range, in Europe and Japan.

The extensive range of the Whooper Swan and the considerable area of suitable habitat available for it in Russia, makes it clear that substantial further research efforts should focus on that country. Topics well worthy of future research include: elucidating from which breeding areas wintering populations migrate; confirming and protecting the main stop-over sites used by migrating Whooper Swans along their various flyways; further investigation of areas where confusion over swan identity has rendered past data unusable, and establishing the norms for breeding densities for the various habitats used by Whooper Swans in Russia, so that future change can be monitored.

\section{Acknowledgements}

We dedicate this review of the Whooper Swan's status and distribution in Russia to the memory of Dr Yuri Schadilov, of the Russian Institute of Nature Conservation, Moscow, leading Russian swan biologist, who died in August 2001.

For their help in providing additional information facilitating the completion of this paper we are grateful to: Mr Alexander Abuladze, Dr Sergei Bukreev, Mr Vladimir Dinets, Dr Eugene Syroechkovskiy Jr, Dr Lev Vartapetov, and Mr Oleg Zhuk. We also thank several anonymous referees who provided important input to an earlier draft, and Eng-Li Green of Alcedo Publishing for preparing the maps.

\section{References}

Adam, A. M., Bayandin, O. V., Gurev, S. P., Dubovik, A. D., Kilim, S. V., Lyalin, V. G. \& Milovidov, S. P. 1990. Lebed-klikun v Tomskom Priboie [The Whooper Swan in Tomsk Ob R. area]. pp. 30-31 in: Ekologiya i okhrana lebedei v SSSR [Ecology and conservation of swans in the USSR]. Vtoroe vsesoyuznoe soveshchanie po lebedyam [The Second Meeting on Swans]. Odessa, 20-24 September 1988. Melitopol State Pedagogical Institute, Melitopol.

Antipov, A. M. 2001a. Struktura naseleniya i dinamika chislennosti lebedya-klikuna v federal'nom zakaznike "Elizarovskiy" (Khanty-Mansijskiy avtonomnyi okrug) v 1977-1983 [Population structure and dynamics of the Whooper Swan in the "Elizarovskiy" Federal Nature Refuge (Khanty-Mansi Autonomous Area) in 1977-1985]. pp. 7-8 in: Problemy izucheniya i okhrany guseobraznykh ptits Vostochnoi Evropy i Severnoi Azii. Moscow.

Antipov, A. M. 2001b. Dinamika plotnosti i struktura naseleniya lebedya-klikuna v Srednem Zaural'ie v 19771985. [Density dynamics and population structure of the Whooper Swan in the Middle Zaural'ie in 19771985]. pp. 8-9 in: Problemy izucheniya i okhrany guseobraznykh ptits Vostochnoi Evropy i Severnoi Azii. Moscow. 
Artem'yev, Yu. T. \& Popov, V. A. 1977. Ptitsy Volzhsko-Kamskogo kraya [Birds of Volga-Kama Territory]. Nauka, Moscow.

Baldaev, Kh. F. 1990. The Whooper Swan in Mari Territory (Krai). pp. 72-73 in: Ekologiya i okhrana lebedei $\checkmark$ SSSR [Ecology and conservation of swans in the USSR]. Vtoroe vsesoyuznoe soveshchanie po lebedyam [The Second Meeting on Swans]. Odessa, 20-24 September 1988. Melitopol State Pedagogical Institute, Melitopol.

Barabashin, T. O., Borodin, O. V., \& Kiryashin, V. V. 2001. Redkie guseobraznye Ul'yanovskoi oblasti [Rare Anseriformes of Ul'yanovsk Region]. p. 14 in: Popovkina, A. B. (Ed.), Problemy izucheniya $i$ okhrany guseobraznykh ptits Vostochnoi Evropy $i$ Severnoi Azii [Problems of study and conservation of Anseriformes of Eastern Europe and Northern Asia]. Tez. dokl. [Abstracts of 1st Meeting of Working Group on Geese and Swans of Eastern Europe and Northern Asia, Moscow, 25-27 January 2001]. Moscow.

Baranov, A. A. 1990. Data on distribution of the Whooper Swan in Tuva. pp. 31-32 in: Ekologiya i okhrana lebedei v SSSR [Ecology and conservation of swans in the USSR]. Vtoroe vsesoyuznoe soveshchanie po lebedyam [The Second Meeting on Swans]. Odessa, 20-24 September 1988. Melitopol State Pedagogical Institute, Melitopol.

Belik, V. P. 1990. Swans in Rostov Region. pp. 73-76 in: Ekologiya i okhrana lebedei v SSSR [Ecology and conservation of swans in the USSR]. Vtoroe vsesoyuznoe soveshchanie po lebedyam [The Second Meeting on Swans]. Odessa, 20-24 September 1988. Melitopol State Pedagogical Institute, Melitopol.

Bianki, V. V. 1990. E ekologii lebedya-klikuna na Kol'skom poluostrove [On the Whooper Swan ecology in the Kola Peninsula]. pp. 76-81 in: Ekologiya i okhrana lebedei v SSSR [Ecology and conservation of swans in the USSR]. Vtoroe vsesoyuznoe soveshchanie po lebedyam [The Second Meeting on Swans]. Odessa, 2024 September 1988. Melitopol State Pedagogical Institute, Melitopol.

Bianki, V. V. \& Shutova, E. V. 1987. Razmeshchenie i chislennost' lebedei na severe evropeiskoi chasti SSSR [Distribution and number of swans in the north of the European part of the USSR]. pp. 20-28 in: Ekologiya $i$ migratsii lebedei $v$ SSSR [Ecology and Migrations in the USSR]. Nauka, Moscow.

Blinova, T. K. \& Blinov, V. N. 1997. Ptitsy yuzhnogo Zaural'ya. Lesostep I step. Vol. 1. Faunisticheskiy obzor $i$ okhrana ptits. [Birds of southern Trans-Uralia. Forest-steppe and steppe]. Nauka, Novosibirsk.

Bragin, A. B. 1987. Okhrana i gnezdovanie lebedya-klikuna v Laplandskom zapovednike [Conservation and breeding of the Whooper Swan in the Lapland Nature Reserve]. pp. 142-143 in: Ekologiya $i$ migratsii lebedei $v$ SSSR [Ecology and Migrations of Swans in the USSR]. Nauka, Moscow.

Braude, M. I. 1998. Uvelichenie chislennosti lebedei v Kurganskoi oblastoi [The swan number increase in Kurgan Region]. Materialy k rasprostraneniyu ptits na Urale, v Priural'ie I Zapadnoi Sibiri [Materials on bird distribution in the Urals, in cis-Uralia and West Siberia]. Ekaterinburg.

Brazil, M. A. 1981. The behavioural ecology of the Whooper Swan (Cygnus cygnus cygnus). Ph.D. Thesis; Stirling University.

Brazil, M. A. 1991. The Birds of Japan. Helm, London.

Brazil, M. A. (in press) The Whooper Swan. Poyser, London.

Brazil, M. A. \& Shergalin, J. (in press) The Status and Distribution of the Whooper Swan Cygnus cygnus in Russia II: Central and Eastern Siberia, and the Russian Far East. Journal of Yamashina Institute for Ornithology 34.

CIA. 2002. The World Factbook: Russia. www.cia.gov/cia/publications/factbook/geos/rs.html

Delany, S., Reyes, C., Hubert, E., Pihl, S., Rees, E., Haanstra, L. \& van Strien, A. 1999. Results from the International Waterbird Census in the Western Palaearctic and Southwest Asia, 1995 and 1996. Wetlands International Publication No. 54, Wageningen.

Dinets V. L. 1997. Birds (in: Encyclopedia of Russian Nature). ABF, Moscow.

Earnst, S. L. 1991. The Third International Swan Symposium. Wildfowl Supplement No. 1: 7-14.

Emel'yanov, V. I. \& Savchenko, A. P. 1990. Distribution and number of the Whooper Swan in the period of seasonal migrations in the south of Middle Siberia. pp. 42-46 in: Ekologiya i okhrana lebedei $v$ SSSR [Ecology and conservation of swans in the USSR]. Vtoroe vsesoyuznoe soveshchanie po lebedyam [The Second Meeting on Swans]. Odessa, 20-24 September 1988. Melitopol State Pedagogical Institute, Melitopol. 
Fedorov, E. G. \& Khodkov, G. I. 1987. Lebed'-klikun na vodoemakh Tsentral'noi Baraby (Zapadnaya Sibir') [The Whooper Swan on water bodies of Central Baraba (West Siberia)]. pp. 100-102 in: Ekologiya $i$ migratsii lebedei $v$ SSSR [Ecology and Migrations in the USSR]. Nauka, Moscow.

Gerasimov, Yu. N., Sal'nikov, G. M. \& Buslaev, S. V. 2000. Ptitsy Ivanovskoi oblasti [Birds of Ivanovo Region]. Rossel'khozakademii Typ., Moscow.

Golovan, V. I. \& Kondratiev, A. V. 1999. Gnezdovanie lebedya-klikuna Cygnus cygnus v Leningradskoi oblasti [The Whooper Swan Cygnus cygnus breeding in Leningrad Region]. Russ. Orn. Zhurnal [Russian Journal of Ornithology] Express-issue 86: 11-12.

Gordienko, N. S. 2001. Sovremennoe sostoyanie lebedei i gusei v Yuzhnom Zaurtal'ye [Modern status of swans and geese in Southern Trans-Uralia]. pp. 36-37 in: Popovkina, A. B. (Ed.), Problemy izucheniya i okhrany guseobraznykh ptits Vostochnoi Evropy $i$ Severnoi Azii [Problems of study and conservation of Anseriformes of Eastern Europe and Northern Asia]. Tez. dokl. [Abstracts of 1st Meeting of Working Group on Geese and Swans of Eastern Europe and Northern Asia, Moscow, 25-27 January 2001]. Moscow.

Gorelov, M. S., Gorshkov, Yu. A., Emelin, G. A. \& Prokhorov, E. V. 1987. O gnezdovanii lebedei v Kuibyshevskoi oblasti [On swan nesting in Kuibyshev Region]. pp. 131-132 in: Ekologiya i migratsii lebedei v SSSR [Ecology and Migrations in the USSR]. Nauka, Moscow.

Haapanen, A. \& Hautala, H. 1991. Bimodality of spring migration of the Whooper Swan Cygnus cygnus in Finland. Wildfowl Supplement 1: 195-200.

Hoklova, T. Y. \& Artemyev, A. V. in press. Modern distribution of the Whooper Swan Cygnus cygnus (L.) in the north-west of Russia. Proceedings of the 4th International Swan Symposium, Airlie, Virginia.

Kalyakin, V. N. 1999. Ptitsy Novozemel'skogo regiona i Zemli Frantsa-Iosifa [Birds of Novaya Zemlya Region and Frants-Josef Land]. pp. 109-137 in: Materialy krasprostraneniyu ptits na Urale, v Priural'ye i Zapadnoi Sibiri [Materials on bird distribution in Ural, Cis-Ural area and West Siberia]. Ekaterinburg.

Karyakin, I. V. \& Kozlov, A. A. 1999. Predvaritel'nyi kadastr ptits Chelyabinskoi oblasti [Preliminary cadastre of birds of Chelyabinsk Region]. Manuscript Publishing House, Novosibirsk.

Khokhlova, T. Yu. \& Artem'yev, A. V. 2000. Gnezdovanie lebedya-klikuna Cygnus cygnus v Kenozerskom natsionalnom parke (Arkhangelskaya oblast) [The Whooper Swan Cygnus cygnus nesting in the Kenozero National Park (Arkhangelsk Region)]. Russ. Orn. Zhurnal [Russian Journal of Ornithology] Express issue 102: 22-23.

Klimov, S. M., Zemlyanukhin, A. I., Sarychev, V. S., Mel'nikov, M. V. 2001. Ptitsy basseina Verkhnego Dona: Anseriformes [The birds of the Upper Don basin: Anseriformes]. Russkiy Ornitologicheskiy Zhurnal [Russ. J. Ornithol] Express-issue 149: 523-543.

Kornev, S. V. \& Korshikov, L. V. 1995. O gnezdovanii lebedya-klikuna v Orenburgskom Zaural'ye [On the Whooper Swan in Orenburg steppe Trans-Uralia]. In: Zhivotnyi mir Yuzhnogo Urala i Severnogo Prikaspiya. [Wildlife of the Southern Ural and Northern Caspian Sea area]. Orenburg State Pedagogical Institute Press, Orenburg.

Kotyukov, Yu. V. 1990. Swans in Ryazan Region. pp. 87-90 in: Ekologiya i okhrana lebedei v SSSR [Ecology and conservation of swans in the USSR]. Vtoroe vsesoyuznoe soveshchanie po lebedyam [The Second Meeting on Swans]. Odessa, 20-24 September 1988. Melitopol State Pedagogical Institute, Melitopol.

Krivenko, V. G., Molochaev, A. V., Borshchevskiy, V. G., Azarov, V. I. \& Martyshin, T. N. 1984. Rezul'taty ucheta lebedya-klikuna v Yamalo-Nenetskom avronomnom okruge [Results of the Whooper Swan census in Yamal-Nenets Autonomous District]. pp. 132-133 in: Sovremennoe sostoyanie resursov vodoplavayushchikh ptits (Tezisy vsesoyuznogo seminara 20-23 October 1984) [Modern status of waterfowl resources (abstracts of Seminar 20-23 October 1984)]. Moscow.

Kuchin, A. P. 1988. [Over wintering of the Whooper Swan in the Altai]. pp. 135-137 in: Shvetsov, Yu. G. (Ed.) Redkie nazemnye pozvonochnye Sibiri. Nauka, Novosibirsk.

Kuchin, A. P. 2001a. Vekovaya i sezonnaya dinamika klimata Altaya i eyo vliyanie na migratsii i zimovki ptits [Century-long and seasonal dynamics of climate of Altai and its influence on migrations and wintering of birds]. pp. 351-352 in: Aktual'nye problemy izucheniya $i$ okhrany ptits Vostochnoi Evropy $i$ Severnoi Azii [Actual problems of study and conservation of birds of Eastern Europe and Northern Asia]. Matbugat Jorty Press, Kazan. 
Kuchin, A. P. 2001b. Red Data Book of Altai. www.gasu.gorny.ru/virt/rb/7/d710.html

Kuchin, A. P. \& Kuchina, N. A. 1990. The Whooper Swan in Altai Krai (Territory). pp. 53-55 in: Ekologiya $i$ okhrana lebedei $v$ SSSR [Ecology and conservation of swans in the USSR]. Vtoroe vsesoyuznoe soveshchanie po lebedyam [The Second Meeting on Swans]. Odessa, 20-24 September 1988. Melitopol State Pedagogical Institute, Melitopol.

Laubek, B., Nilsson, L., Wieloch, M., Koffijberg, K., Sudfelt, C. \& Folkestad, A. 1999. Distribution, numbers and habitat choice of the NW European Whooper Swan (Cygnus cygnus) population: results of an international census in January 1995. Vogelwelt 120: 141-154.

Li, X. 1996. Numerical distribution and conservation of Whooper Swans (Cygnus cygnus) in China. Gibier Faune Sauvage, Game Wildlife 13: 477-486.

Lysenko, E. V., Lapshin, A. S., Simonov, D. V. \& Kolyganova, M. V. 1997. Redkie ptitsy Mordovii [Rare birds of Mordovia]. pp. 35-41 in: Fauna, ekologiya i okhrana redkikh ptits Srednego Povolzh'ya [Fauna, ecology and conservation of rare birds of the Middle Volga River area]. Saransk.

Ma, M. 1996. The status and breeding ecology of Whooper Swans Cygnus cygnus in Bayinbuluke, Xinjiang, China. Swan Specialist Group Newsletter 5: 15-19.

Madge, S. \& Burn, H. 1988. Wildfowl. An identification guide to the ducks, geese and swans of the world. Christopher Helm, London.

Mikhaleva, E. V. 1997. Popytka gnezdovaniya lebedya-klikuna Cygnus cygnus na Valaamskom arkhipelage (Ladozhskoe ozero) [The Whooper Swan Cygnus cygnus attempted to nest on the Valaam Archipelago (Ladoga Lake) in June 1997]. Russ. Orn. Zhurnal [Russian Journal of Ornithology] Express issue 25: 1920.

Miller, I. D. \& Skalon, O. V. 1990. Novye dannye o gnezdovanii lebedya-shipuna v Tul'skoi oblasti [New data on the Mute Swan nesting in Tula Region]. pp. 96-97 in: Ekologiya i okhrana lebedei v SSSR [Ecology and conservation of swans in the USSR]. Vtoroe vsesoyuznoe soveshchanie po lebedyam [The Second Meeting on Swans]. Odessa, 20-24 September 1988. Melitopol State Pedagogical Institute, Melitopol.

Mineev, Yu. N. 1995. Lebed-klikun [Whooper Swan]. pp. 29-32 in: Fauna Evropeiskogo Severo-Vostoka Rossii [Fauna of European North-East of Russia]. Ptitsy [Birds]. Vol. 1. Part 1. Nauka, St. Petersburg.

Mineev, O. Yu. 2000. Materialy po faune vodoplavayushchikh ptits basseina reki Indigi [Data on the waterfowl fauna of the Indiga River basin]. Casarca 6: 299-301.

Mitchell, C. D. \& Rotella, J. J. 1997. Brood amalgamation in Trumpeter Swans. Wildfowl 48: 1-5.

Nikolaev, V. I. 1998. Ptitsy bolotnykh landshaftov natsional'nogo parka "Zavidovo" $i$ Verkhnevolzh'ya. [Birds of marsh landscapes of National Park "Zavidovo" and Upper Volga River area]. Tver'.

Ohtonen, A. 1992. Increasing trend in the Whooper Swan population. Suomen Riista 38: 34-44.

Perennou, C., Mundkur, T. \& Scott, D. A. 1994. The Asian Waterfowl Census 1987-1991: Distribution and Status of Asian Waterfowl. AWNB Publication No. 86/IWRB Publication No. 24.

Poyarkov, N. D. \& Johnson, S. R. 1996. The unique productivity of the Whooper Swan in the middle reaches of the $\mathrm{Ob}$ river (Khanty-Mansi autonomous district). Casarca 2: 230-235.

Ravkin, Yu. S. 1991. Number and distribution of Mute Swans Cygnus olor, Bewick's Swans C. bewickii, and Whooper Swans C. cygnus in the West Siberian plain. Wildfowl Supplement 1: 68-72.

Ravkin, Yu. S., Vartapetov, L. G., Milovidov, S. P., Adam, A. M. \& Fomin, B. N. 1990. Number and distribution of swans in West-Siberian Plain (forest-tundra, forest zone, forest-steppe and steppe). pp. 5558 in: Ekologiya $i$ okhrana lebedei $v$ SSSR [Ecology and conservation of swans in the USSR]. Vtoroe vsesoyuznoe soveshchanie po lebedyam [The Second Meeting on Swans]. Odessa, 20-24 September 1988. Melitopol State Pedagogical Institute, Melitopol.

Rees, E. C., Einarsson, O. \& Laubek, B. 1997. Cygnus cygnus Whooper Swan. BWP Update 1(1): 27-35.

Rüger, A., Prentice, C. \& Owen, M. 1986. Results of the IWRB international waterfowl census 1967-1983. Population estimates and trends in selected species of ducks, swans and coot from January counts in the Western Palearctic. IWRB Special Publication 6: 1-118.

Rusanov, G. M. 1987. Sostoyanie i rol' zimovochnykgh ugodiy lebedei-klikunov na Severnom Kaspii [The status and role of wintering habitats of the Whooper Swan in the Northern Caspian Sea]. pp. 69-73 in: Ekologiya $i$ migratsii lebedei $v$ SSSR [Ecology and Migrations in the USSR]. Nauka, Moscow. 
Rusanov, G. M. 1990. The success of wintering of Whooper Swan in the Volga River delta. pp. 112-115 in: Ekologiya i okhrana lebedei $v$ SSSR [Ecology and conservation of swans in the USSR]. Vtoroe vsesoyuznoe soveshchanie po lebedyam [The Second Meeting on Swans]. Odessa, 20-24 September 1988. Melitopol State Pedagogical Institute, Melitopol.

Rusanov, G. M., Reutskiy, N. D., Krivonosov, G. A., Gavrilov, N. N., Litvinova, N. A. \& Bondarev, D. V. 1999. Pozvonochnye zhivotnye Astrakhanskogo zapovednika [Vertebrates of Astrakhan Nature Reserve]. M. 75 p. Series "Flora and Fauna of Nature Reserves.

Samigullin, G. M. 1990. Distribution and number of swans in Orenburg Region. pp. 117-118 in: Ekologiya $i$ okhrana lebedei $v$ SSSR [Ecology and conservation of swans in the USSR]. Vtoroe vsesoyuznoe soveshchanie po lebedyam [The Second Meeting on Swans]. Odessa, 20-24 September 1988. Melitopol State Pedagogical Institute, Melitopol.

Samigullin, G. M. \& Parasich, O. M. 1995. Lebed-klikun v stepyakh Yuzhnogo Urala [The Whooper Swan in the steppes of Southern Ural]. pp. 70-71 in: Voprosy ornitologii [Problems of Ornithology]. Barnaul.

Sarychev, V. S., Vorob'yov, G. P., Klimov, S. M. \& Nedosekin, Yu. V. 1990. Modern number of swans in Upper Cis-Don River area. pp. 116-117 in: Ekologiya i okhrana lebedei v SSSR [Ecology and conservation of swans in the USSR]. Vtoroe vsesoyuznoe soveshchanie po lebedyam [The Second Meeting on Swans]. Odessa, 20-24 September 1988. Melitopol State Pedagogical Institute, Melitopol.

Schadilov, Yu. M. 1991. Current conservation status and problems of management for swan populations in the USSR. Wildfowl Supplement 1: 376-377.

Schadilov, Yu. M. \& Belousova, A. V. 2001. Rasprostranenie i dinamika chislennosti trekh vidov lebedei v Rossii: sravnitel'nyi analiz [Distribution and number dynamics of three swan species in Russia: comparative analysis]. pp. 134-135 in: Popovkina, A. B. (Ed.), Problemy izucheniya i okhrany guseobraznykh ptits Vostochnoi Evropy i Severnoi Azii [Problems of study and conservation of Anseriformes of Eastern Europe and Northern Asia]. Tez. dokl. [Abstracts of 1st Meeting of Working Group on Geese and Swans of Eastern Europe and Northern Asia, Moscow, 25-27 January 2001]. Moscow.

Schadilov, Yu. M., Rees, E. C., Belousova, A. V. \& Bowler, J. M. (in press) Population structure of Bewick's and Whooper Swans breeding in northern European Russia. Proceedings of the 4th International Swan Symposium, Airlie, Virginia.

Scott, D. A, \& Rose, P. M. 1996. Atlas of Anatidae in Africa and Western Eurasia. Wetlands International Publication No. 41; Wetlands International, Wageningen, The Netherlands.

Semenov-Tyan-Shanskiy, O. I. \& Gilyazov, A. S. 1990. The Whooper Swan ecology in Lapland Nature Reserve. Pp. 118-121 in: Ekologiya i okhrana lebedei v SSSR [Ecology and conservation of swans in the USSR]. Vtoroe vsesoyuznoe soveshchanie po lebedyam [The Second Meeting on Swans]. Odessa, 20-24 September 1988. Melitopol State Pedagogical Institute, Melitopol.

Shevchenko, V. L., Debelo, P. V., Gavrilov, E. I., Naglov, V. A. \& Fedosenko, A. K. 1993. Ob ornitofaune Volzhsko-Ural'skogo mezhdurech'ya [On ornithofauna of the Volga-Ural interstream area]. Fauna i biologiya ptits Kazakhstana [Fauna and biology of birds of Kazakhstan]. Almaty.

Sotnikov, V. N. 1999. Ptitsy Kirovskoi oblasti $i$ sopredel'nykh territoriy [Birds of Kirov Region and adjoining territories (Vol. 1. Non-Passerines)]. Triada-S Press, Kirov.

Stepanyan, L.S. 1990. Konspekt ornitologicheskoi fauny SSSR [Conspectus of ornithological fauna of the USSR]. Nauka, Moscow.

Tirskiy, D. I. 2001. Osobennosti migratsii goseobraznykh v srednem techenii reki Olekmy [Peculiarities of Anseriformes in the middle stream of Olekma River, (Sakha-Yakutia)]. pp. 126-127 in: Popovkina, A. B. (Ed.), Problemy izucheniya i okhrany guseobraznykh ptits Vostochnoi Evropy i Severnoi Azii [Problems of study and conservation of Anseriformes of Eastern Europe and Northern Asia]. Tez. dokl. [Abstracts of 1st Meeting of Working Group on Geese and Swans of Eastern Europe and Northern Asia, Moscow, 2527 January 2001]. Moscow.

Vartapetov, L. G. 1984. Ptitsy taezhnykh mezhdurechiy Zapadnoi Sibiri. [Birds of the taiga interstream areas of West Siberia]. Nauka, Novosibirsk.

Vartapetov, L. G. 1998. Ptitsy severnoi taigi Zapadno-Sibirskoi ravniny [Birds of northern taiga of West-Siberian Plain]. Nauka, Novosibirsk. 
Vengerov, M. P. 1990a. Moult of the Whooper Swan in the flood-land of Lower Ob River (Khanty-Mansi district of Tyumen Region). pp. 35-36 in: Ekologiya i okhrana lebedei v SSSR [Ecology and conservation of swans in the USSR]. Vtoroe vsesoyuznoe soveshchanie po lebedyam [The Second Meeting on Swans]. Odessa, 20-24 September 1988. Melitopol State Pedagogical Institute, Melitopol.

Vengerov, M. P. 1990b. The Whooper Swan breeding in Khanty-Mansijsk district of Tyumen Region. pp. 3639 in: Ekologiya $i$ okhrana lebedei $v$ SSSR [Ecology and conservation of swans in the USSR]. Vtoroe vsesoyuznoe soveshchanie po lebedyam [The Second Meeting on Swans]. Odessa, 20-24 September 1988. Melitopol State Pedagogical Institute, Melitopol.

Vysotskiy, V. G. 1998. Sluchai gnezdovaniya lebedya-klikuna Cygnus cygnus na yuzhnom beregu Ladozhskogo ozera [The Whooper Swan Cygnus cygnus nesting on the southern shore of Ladoga Lake]. Russ. Orn. Zhurnal [Russian Journal of Ornithology] 33: 10-11.

Yakimenko, V. V. 1997. Rasprostranenie i chislennost lebedya-klikuna (Cygnus cygnus) v Omskoi oblasti [Distribution and number of the Whooper Swan (Cygnus cygnus) in Omsk Region]. Byulleten rabochei gruppy po gusyam i lebedyam Vostochnoi Evropy i Severnoi Azii [Bulletin of Goose and Swan Study Group of Eastern Europe and North Asia] 3: 272-279.

Zabelin, M. M. 1996. Zametki o taezhnom gumennike i lebede-klikune v Turukhanskom raione Krasnoyarskogo kraya [On the Taiga Bean Goose and Whooper Swan in the Turukhan District, Krasnoyarsk Territory]. Casarca 2: 308-312.

\section{ロシアにおけるオオハクチョウの生息状況と分布 $\mathbf{I} ：$ ロアア西部とシベリア西部}

オオハクチョウ (Cygnus cygnus) の生息域の大半は, ロシアおよびその周辺の旧ソ連邦共和 国の境界内に含まれている。従来, 本種に関する研究の多くは, ヨーロッパと日本で行なわれ てきたが, 1980 年以降, ロシアであかなりの量の研究が行なわれるようになった。これらの研 究の大半はロシア国内の論文誌，それあ地方の論文誌で発表されることが多いため，ロシア以 外の研究者がこれらの文献に接したり，入手したりする機会は非常に限られている。このたび 私たちは，本種を対象とした，ロシア国内の 4 地域における文献を整理，検討した。

そして,これら 4 地域：1）ロシア西部（ウラル山脈の西側）2）シベリア西部（ウラル山脈東 側からエニセイ川まで） 3) シベリア中東部（エニセイ川からレナ川まで）4）ロシア極東部（レ ナ川からベーリング海まで）における本種の個体数, 繁殖生態, 越冬地の範囲, 渡り, 換羽行 動についても，おおよその全体像を求めてみた。この 4 地域の面積はいずれも，ヨーロッパ個 体群が占有する面積とほぼ同じ，あるいははるかに上回っているかである。また，現在，個体 群の大きさに関する正確な情報が入手できるのは，この 4 地域のみである。なお，本号では口 シア西部とシベリア西部，次号ではシベリア中東部とロシア極東部を報告する。

ロシアのオオ八クチョウ個体群は大きく，お抗称安定している。また，北に向かって生息 域を拡大しつつあると推定される。これらの個体群は, 生息環境の擋乱や悪化, 生息地の消失, 狩猟などさまざまな人為的影響に悩まされているが, 場所によっては, 先に述べたような否定 的影響が減少して, 繁殖地を取り戻しつつあるところもある。ロシアのオオ八クチョウは, 北 西部のコラ半島から東部のチュコト半島のアナディル渓谷とカムチャツカにかけて分布してい る。繁殖域の北限は通常, 北緯 67〜 68 度付近であるが, 場合によっては北緯 70 度まで, まれ に北緯 72 度まで北上して繁殖した例があり, 繁殖域の北限が徐々に北上しつつあるという状 況証拠にあなっている。ヨーロッパロシア西部におけるオオ八クチョウの繁殖域の南限は北緯 62 度であるが, サハリンやカムチャツカでは北緯 50〜 55 度まで南下する。西部のオオ八ク チョウは北緯 47〜 50 度付近まで南下して越冬するが, 最も南の越冬地は日本にある。これは気 
候的な理由によるもので，日本では北緯 35 40 度にかけての低緯度地域に多数の個体が越冬 しているのが観察される。ロシアではオオ八クチョウは, タイガ北部と森林ッンドラおよびッ ンドラの一部で繁殖する鳥である。オオ八クチョウの個体数と生息域は, 20 世紀半ばに生じた 人為的影響により，一部の地域，特に西部で，19 世紀から 20 世紀初頭のレベルにまで減少し た。しかしながら，20世紀後半になると才オ八クチョウはかつての分布域を取り戻し始めた。 推定個体数は同一地域であ報告によって大幅に異なる．例えば，ロシア西部とシベリア西部 の地域での個体数は 1 万羽程度加ら 10 万羽以上と推定されている (Ravkin 1991, Rees et al. 1997)。このため, 全個体数を推定することは事実上不可能である。最大のオオ八クチョウ生息 地であるこの地には，かなりの研究の余地がある。カムチャッカ，日本，朝鮮半島および中国 に打ける越冬個体数から推定すると，ロシア極東部には約 6 万羽が生息していると考えられ る。世界のオオ八クチョウの大多数はロシア国内で繁殖を行なうが，そのほとんどはロシア国 境を越え, バルト海, カスピ海, 日本海周辺などの近隣の国々で越冬する。渡りの時期は地方 によって異なるが，少なくとも秋の渡りは，急激な気温の降下，特に日中の気温が $5^{\circ} \mathrm{C}$ から $0^{\circ} \mathrm{C}$ に降下することが引き金になっているらしい。ロシア各地で得られた記録からは，春と秋の渡 りにいくつかの波があることがわかる。春の渡りでは, 前半はつがいや家族が優勢で, 後半は 非繁殖個体が多くなる。秋には非繁殖個体のほうが繁殖個体より早めに渡り始める。これは, 初期の渡りの群れには幼鳥が少なく, 後半になるとつがいや家族, 七大連れの群れが多くなる ことからもわかる。生息域の西側では，オオ八クチョウが，コブハクチョウ (Cygnus olor)やコ 八クチョウ (Cygnus columbianus bewickii) と一緒に渡りをしているのが観察されることもあ る。また東側では,コハクチョウと同じ中継地点を利用することが多い。

現在のロシア国境内に捛けるオオ八クチョウ繁殖地は広く，在住の八クチョウ研究者は少な い。そのうえ，交通の便の悪い地域が大半という条件下では，最低限の基礎情報すら得られな い地域があっても驚くに値しない。それにもかかわらずここ数十年の間にロシア国内で多数の 論文が発表されていることは，素晴らしいことである。本論文で言及したロシア西部とシべリ ア西部の 2 地域およびシベリア中東部とロシア極東部の 2 地域 (Brazil \& Shergalin in press) の これらロシア 4 地域のスケールの大きさや，この 4 地域のオオ八クチョウ生息適地の広大さを 考えると，今後，本種の正確な生息状況を明らかにしようと思えば，ロシアに目を向けねばな らないことは明白である。

(摘要和訳 黒沢優子)

マーク・A・ブラジル：酪農学園大学環境システム学科, テ069-8501 北海道江別市文京台 緑町 582.

イェフゲニ・シャーガリン: “Zoolit”, Sopruse pst. 175-58, Tallinn 13413, Estonia.

E-mail: zoolit@hotmail.com 